University of Rhode Island

DigitalCommons@URI

Open Access Master's Theses

1999

\title{
The Foundation of Radical Ecological Philosophy in Karl Marx's View of Nature
}

\author{
Elizabeth Marsis \\ University of Rhode Island, lizmarsis@icloud.com
}

Follow this and additional works at: https://digitalcommons.uri.edu/theses

\section{Recommended Citation}

Marsis, Elizabeth, "The Foundation of Radical Ecological Philosophy in Karl Marx's View of Nature" (1999). Open Access Master's Theses. Paper 284.

https://digitalcommons.uri.edu/theses/284

This Thesis is brought to you for free and open access by DigitalCommons@URI. It has been accepted for inclusion in Open Access Master's Theses by an authorized administrator of DigitalCommons@URI. For more information, please contact digitalcommons-group@uri.edu. 
THE FOUNDATION OF RADICAL ECOLOGICAL PHILOSOPHY IN KARL MARX'S VIEW OF NATURE

BY

ELIZABETH MARSIS

A THESIS SUBMITTED IN PARTIAL FULFILLMENT OF THE REQUIREMENTS FOR THE DEGREE OF

MASTER OF ARTS

IN

PHILOSOPHY

THE UNIVERSITY OF RHODE ISLAND

1999 
MASTER OF ARTS THESIS

OF

ELIZABETH MARIS

APPROVED:

Thesis Committee
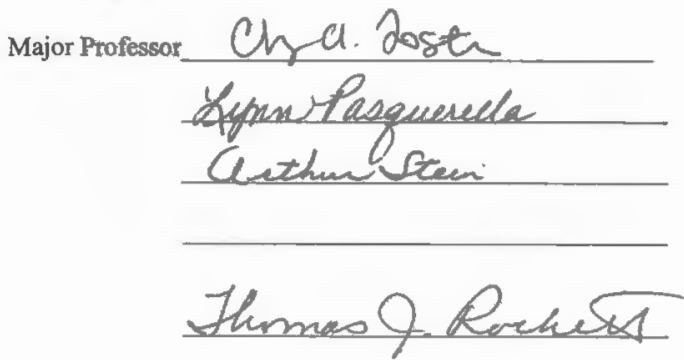

DEAN OF THE GRADUATE SCHOOL

THE UNIVERSITY OF RHODE ISLAND 1999 


\begin{abstract}
The three main non-traditional schools of environmental philosophy - social ecology, feminism and deep ecology - contain divergent views of and claims regarding the universalization of their particular world views. One example of this divergence of views concerns the status of human/non-human relationships. Like many other contemporary non-traditional liberation movements and theories, these three environmental movements and schools of thought have been influenced by the theories of Karl Marx.

Therefore, in order to clarify and understand the way in which, and the extent to which, key proponents of each of these environmental movements and philosophies universalize their particular philosophic world views, this thesis compares their theories to those of Karl Marx. Emphasis is placed on Marx's critique of abstract and idealistbased universalizing as applied in the area of human-non-human relationships, as this critique and area of application is a key feature of non-traditional environmental thought. Also, the methodology used in this thesis is a critical analysis of the primary philosophic texts and related commentaries.
\end{abstract}




\section{ACKNOWLEDGMENT}

I would like to acknowledge the many persons who have made the completion of the thesis possible. I would like to thank Dr. Cheryl Foster, my major professor, for guiding me toward refining and reducing the scope of my arguments. I would also like to thank Philosophy Department Chair Lynn Pasquerella for facilitating the process of preparing my thesis for defense. A special thanks goes to Dr. Galen Johnson, both for supporting me in my goals (which required a special time exemption) and for academically guiding me through the process of a postmodern critique of the theories of Karl Marx. Without his assistance and direction in resources, clarifying my own philosophical concerns would have been a near impossibility. Thank you to Dr. Arthur Stein, for his willingness to be an active member of my thesis committee, and his responsiveness and positive feedback on my work during its various stages of progress. Also, thank you to Dr. Nancy Cook, for agreeing to be my Defense Committee Chair. I would be remiss if I did not thank the Philosophy Department staff and faculty members and Graduate School deans who allowed me to complete my studies, as well as the many friends and family members who kept encouraging me, despite the seeming opposition of my life circumstances. 
Abstract

Acknowledgment

Table of Contents

Preface

Chapter 1: Marx's View of Nature

Chapter 2: Bookchin's View of Nature

Chapter 3: Warren: A Pluralist Ecofeminism

Chapter 4: Naess: Concrete Value Relations

Conclusion

Appendix

Bibliography ii

iii

iv

$v$ - vi

1

29

48

69

85

87

88 
PREFACE

Ecological philosophy may be defined as a subject area within philosophy that focuses on "relations to nature" and studies "problem[s] at the vast juncture between the two well-recognised disciplines"1 of ecology and philosophy. Among philosophers writing about this new ${ }^{2}$ topic in philosophy, those engaged in radical eco-politics ${ }^{3}$ can be identified by their commonly held views that 1) non-human nature is integrated with the physical, conscious and human social experience of reality; and 2) the interactive, concrete relations between human and non-human nature (human/nature ${ }^{4}$ ) are at the foundation of philosophic investigation. These two views, however, are not unique to politically radical, ecological philosophers. The ideas that 1) non-human nature is directly linked to humanity's physical, conscious and social experiences; and 2) dynamic and concrete human/nature relationships serve as the basis of philosophy, were presented in the early writings of Karl Marx.

This paper attempts to clarify the indebtedness of politically radical ecological philosophy to Marx's philosophy, with regard to the above points "1)" and "2)." This study examines positions of one representative philosopher within each of the three main ecopolitical groups: Murray Bookchin, whose thought is aligned with that of

1 Naess, Arne, Ecology, Community and Lifestyle, translated by Rothenberg, David, (Cambridge: Cambridge University Press, 1989), p. 36.

2 The term "ecology" gained widespread acceptance as a topic of philosophy in the late 1960's and early 1970's, as evidenced by its appearance in the "Subject Index" of the Philosopher's Index 1970.

3 Philosophers engaged in radical politics on the basis of their ecological outlook can be divided into three main groups: "social ecology, deep ecology, and ecological feminism." Plumwood, Val, "The Ecopolitics Debate and the Politics of Nature," Ecological Feminism, Edited by Warren, Karen J. (New York: Routledge, 1994), p. 65. 4 The term "human/nature" shall be used throughout this paper to replace the lengthier phrase, "human and non-human nature." 
social ecology; Karen Warren, who emerges from the ecofeminist movement; and Arme Naess, who founded the philosophical view called 'deep ecology'.

Chapter 1 explores Marx's view of the human/nature relationship, illustrating that his interpretation of "naturalism or humanism"s serves as the foundation of his approach to the field of philosophy. Emphasis is placed on relevant discussions in The Economic and Philosophic Manuscripts of 1844 and The German Ideology. Marx's version of "naturalism or humanism," founded on a new understanding of human/nature relations, reverberates throughout the philosophies of Bookchin, Warren and Naess. Chapters 2, 3 and 4 focus on key aspects of their works, aspects that rely on and expand on Marx's understanding of human/nature relations as a) a dynamic, concrete relationship between non-human nature and human consciousness; and b) the basis for "realistic" philosophy, which holds "that material objects exist externally to us and independently of our sense experience.»

5 Marx, Karl "Economic and Philosophic Manuscripts of 1844," Collected Works 3, (New York: International Publishers, 1975) p. 336.

- Realism opposes "idealism, which holds that no such material objects or external realities exist apart from our knowledge or consciousness of them, the whole universe thus being dependent on the mind or in some sense mental." Hirst, R. J., "Realism," Encyclopedia of Philosophy, Vol. 7, Edwards, Paul, Ed., (NY: Macmillan Publishing Co., Inc., 1972), p. 77. Independent existence, however, does not preclude relationality: recognition of the independent existence of material objects requires a conscious observer. This view, articulated by Marx in his critique of idealism, emerged as "New Realism." New Realists argue that "even if it is true that whenever something is being perceived, it is an object for a mind, it does not follow that it has no existence except by being perceived. Hence, the idealist commits a fallacy if he concludes that the whole world is nothing but ideas from the truism that when something is known, it is an object for a mind." Ramsperger, A. G., "Critical Realism," Vol. 2, p. 261. 
CHAPTER 1: MARX'S VIEW OF HUMAN/NATURE RELATIONS

This chapter examines Marx's concept of human/nature relations, in which human and non-human nature are understood as unified dimensions within the dialectical process ${ }^{7}$ of human activity (labor). In light of the dialectic, Marx's concept of the human/nature relationship is best understood as a unity that develops in three historical steps, culminating in the emergence of communism as the human "society" which fully expresses the human potential embedded in the unity of "man and nature." In the first step, humanity is, for Marx, merely the human species in a pre-historical and pre-theoretic conscious state of development. In the second step, humanity is man - conscious, historical being that perceives itself as other from nature through the activity of labor. In the third and final step (which, Bookchin argues, never comes to fruition), humanity is fully human, historically developed to the point of realizing humanity's potential and recognizing nature as the self-expression of human society in the world. ${ }^{8}$ In what follows, the triadic relations are discussed in order to demonstrate Marx's understanding of human/nature relations. First, what Marx means by humanity and nature is clarified, since humanity as "man" and "woman" doesn't occur until the second stage of the dialectic.

7 Marx uses the term 'dialectic' is a restricted sense. Marx does not use the dialectic to explain anything other than human affairs. Marx applies the dialectic as the principle of change through the systematic unification of two opposing aspects to understand the human causes of various historical, social movements. See Hook, Sidney, From Hegel to Marx, (Michigan: University of Michigan Press, 1962), pp. 72-76.

${ }^{8}$ Bookchin modifies Marx's homocentric view of nature by 1) acknowledging "natural diversity" as an "end in itself;" and 2) by reversing Marx's understanding of the direction of change: "human consciousness and management [is] nature rendered self-conscious and self-active." See Bookchin, Murray, "Toward an Ecological Society," Toward and Ecological Society, (Montreal: Balck Rose Books, 1980), p. 59. 
Marx declares that his approach to philosophy is a synthesis ("unifying truth") of the extremes of idealism and materialism. This approach, that of a "consistent naturalism or humanism," is the "only" correct approach to philosophy.

Here we see how consistent naturalism or humanism is distinct from both idealism and materialism, and constitutes at the same time the unifying truth of both. We see also how only naturalism is capable of comprehending the action of world history.

Marx's particular humanism or naturalism represents a new approach to philosophy, one that emerged from the modern European tradition. Humanism in Europe, since the latter part of the fourteenth century, expresses the attempt begun by Renaissance thinkers to "reintegrate man into the world of nature and history and to interpret him in this perspective." It exalts both the "soul" and the "body." Naturalism, within this historical context of humanism, is the "conviction that man is part of nature - that nature is his realm, that the features which tie him to nature (his body, his needs, his sensations) are essential to him to the point that he cannot abstract from them or ignore them."11

What is meant by Marx's use of the terms "naturalism or humanism?" His language indicates that he understands "naturalism" as a challenge to Hegelian philosophy's claim to comprehend "the action of world history." Marx's position contrasts with that of most 19th century German philosophers, who either viewed the world as primarily a function of an eternal, active universal spirit (as idealists) or as a function of a mechanistic nature which operated without autonomous deviation and according to fixed laws or principles

9 Marx, Karl, "Economic and Philosophic Manuscripts of 1844," Collected Works 3, (New York: International Publishers, 1975) p. 336.

10 Abbagnano, Nicola, trans. by Langiulli, Nino, "Humanism," Encyclopedia of Philosophy, Vol. 4, Op. Cit., pp. 69-70.

1 Ibid., p. 70. 
(as materialists). ${ }^{12}$ Marx's philosophy, while materialist as such, represents a different kind of philosophy ${ }^{13}$, one that is based on human beings in a natural-historical context. It combines the activity of human consciousness with nature so that neither are understood apart from a dynamic historical context. Human activity causes changes in human society (thus affecting human consciousness itself) and in the material world.

The materialist doctrine that men are products of circumstances and upbringing, and that, therefore, changed men are products of other circumstances and changed upbringing, forgets that it is men who change circumstances. ${ }^{14}$

${ }^{1}$ Marx's "naturalism or humanism" challenged 19th century idealism and materialism while also establishing itself as the basis for critiquing any theory not explicitly founded on the scientifically, historically ${ }^{15}$ and experientially verifiable integration of humanity with the material world. In this sense, Marx's position, which marks a radical departure from the metaphysical (in the sense of "removed from sense perception," time and nature)

12 Hook, Sidney, Op. Cit., pp. 28 and 35-36.

13 Marx rejected the "materialism" of the British Empirical tradition because its various doctrines are based on theories which are unrelated to humanity's real-life (i.e. active, social) experience of the world. For example, Marx classifies the individualistic understanding of humanity held by Empiricists as idealistic, as the "individual" is conceived of abstractly (that is removed from the context within which individuals actually exist in.) See Parsons, Howard L., Humanism and Marx's Thought, (Springfield, Illinois: Charles C. Thomas, Publisher, 1971), pp. 6, 40-45 and 170.

14 Marx, Karl, "Theses on Feuerbach III," The Marx-Engels Reader, Edited by Tucker, (New York: W. W. Norton \& Company, Inc., 1972), p. 108.

is Professor Fritz Wenisch pointed out that historical theory, as it is not directly experienced, is also an abstraction which cannot be empirically verified. Although Marx, Bookchin and Warren reject idealist and dualist philosophies, they rely on historical theories of development to justify their positions. Arne Naess, however, rejects an historical approach and argues that all knowledge ultimately is derived logically upon the basis of some first principle, which is believed to be true and derived through experience. Thus, according to Naess, the proper empirical foundation for a philosophy is discerned through an examination of one's most fundamental beliefs. 
foundation of both classical and modern Western philosophy ${ }^{16}$, is a model upon which Bookchin, Warren and Naess expand.

This chapter explores Marx's understanding of the physically dynamic, integrated hu$\mathrm{man} /$ nature relationship as the foundation of his philosophy. It aims to clarify the dynamic unity between humanity and nature that is implied by Marx's interchangeable terms naturalism and humanism. ${ }^{17}$ The first section reviews Marx's claim that the unity of nature (matter) and humanity (consciousness) is a natural aspect of real-life human activity (labor). It will be shown that naturalism is a concept of labor that integrates humanity with nature based on the fact that human activity, which includes the activities of human consciousness, is dependent upon physical reality. It also briefly reviews Marx's critique of idealism and materialism to demonstrate why Marx considers "only naturalism" as the legitimate basis for philosophic investigation. The second section examines humanism as the historical process by which labor transforms nature. It will examine how the process of humanism occurs as a materially-based dialectic during which nature historically acquires both instrumental and intrinsic value. Together these two sections demonstrate that the relationship between the opposites "man" and "nature" is "unified" in society and that this relationship changes, or accomplishes, the expression of various degrees of interpenetration over the course of historical development. It will

\footnotetext{
16 See, Hancock, Roger, "The History of Metaphysics," Encyclopedia of Philosophy, Vol. 5, Op. Cit., p. $289-290$.

17 In several instances in the "Economic and Philosophic Manuscripts of 1844," Marx uses various forms of both root words "nature" and "human" interchangeably. For instance, see Marx, Karl, Collected Works 3, Op. Cit., pp. 296, 303, and 336.
} 
also be demonstrated that this unity of opposites defines Marx's understanding of "naturalism or humanism."

Thus society is the complete unity of man with nature - the true resurrection of nature - the accomplished naturalism of man and the accomplished humanism of nature. ${ }^{18}$

It should be noted that this chapter represents a partial analysis of Marx's view of nature: no attempt is made to compare views presented in the early writings of Marx to the Marx-Engels tradition; ${ }^{39}$ to apply Marxist doctrine to contemporary issues in environmental philosophy; ${ }^{20}$ or to judge whether or not environmentalism is a logical extension of Marxism. ${ }^{21}$

\section{Marx's "naturalism" as the physical unity of human beings and nature.}

This section reviews Marx's understanding of the two aspects of the dialectical process of human activity, "nature" (the material or physical component) and "man" (the self-conscious component). They are reviewed separately, although they are interrelated and, therefore, always occur simultaneously in human life. Emphasis is placed on the emergence of this process from pre-historical nature.

Humanity's physical link to nature forms the foundation of Marx's material approach to philosophy. In an explanatory paragraph immediately following Marx's phrase

\footnotetext{
18 Marx, Karl, "The Economic and Philosophic Manuscripts of 1844," Op. Cit., p. 298.

19 There is no attempt to speculate on his views with regard to Engels's views on nature, as set forth in the Dialectics of Nature forty years after Marx's early writings. Nor will Marx's early writings on "nature" and "production" be compared to the orthodox Marxist interpretation of these terms (an interpretation which Murray Bookchin builds into his critique of Marx.)

20 See, for example, Grundman, Reiner, Marxism \& Ecology (Oxford: Clarendon Press, 1991).

21 See, for example, Parsons, Howard L., Marx and Engels on Ecology, (Westport, Connecticut: Greenwood Press, Inc., 1977).
} 
"naturalism or humanism," he describes the physical aspects of the human/nature relationship in terms that are unequivocally naturalist: "Man is directly a natural being."2z In a very literal sense, humanity is physically part of nature. However, the human/nature relationship of physical unity does not only refer to humanity's physical constitution and requirements for food, water or air; the entire process of living, the activities that comprise being a complete human, physically and spiritually, require a physical exchange with material nature. Both the material and mental activities of life are a natural part of human existence.

Nature is man's inorganic body - nature, that is, insofar as it is not itself human body. Man lives on nature - means that nature is his body, with which he must remain in continuous interchange if he is not to die. That man's physical and spiritual life is linked to nature means simply that nature is linked to itself, for man is part of nature. ${ }^{23}$

This direct relationship with nature, in which "man's" survival is "linked to nature," and "man's" physical body extends into non-human nature, describes an original state of 'immediate unity' in the dialectical development of human/nature relations. This immediate unity, or first stage of dialectical development, is based on the physical aspect of human/nature relations - humanity is of nature, therefore part of nature is human. Human and non-human nature are not separate from each other.

Marx places his philosophy on a natural base that requires the simultaneous existence of living human beings and of inorganic nature. The survival activities of man, both the activities of the human body and those of human consciousness, comprise the "naturalism

\footnotetext{
22 Marx, Karl. "Economic and Philosophic Manuscripts of 1844," Op. Cit., p. 336. 23 Ibid., pp. 276.
} 
of man." Marx points out the facts that 1) to be alive, human beings require interaction with inorganic nature; and 2) all human physical and mental activity requires a living human being. He concludes, therefore, that all human activities, mental and physical, require a "continuous interchange" with inorganic nature.

The fact of the existence of living human beings - physical and conscious beings who are part of a natural system, is the "first fact" which Marx introduces in order to derive his entire argument for historical materialism. Thus, the direct or immediate unity of human and non-human nature is the "natural base" of history.

The first premise of all human history is, of course, the existence of living human individuals. Thus the first fact to be established is the physical organisation of these individuals and their consequent relation to the rest of nature. Of course, we cannot here go either into the actual physical nature of man, or into the natural conditions in which man finds himself - geological, orohydrographical, climatic and so on. The writing of history must always set out from these natural bases and their modification in the course of history through the action of men. ${ }^{24}$

And so, the physical aspect of immediate unity in human-nature relations is a necessary condition for human history. Therefore, for Marx, a Young Hegelian, the purely physical, or directly natural, aspect of human/nature relations is also a presupposition for philosophy, philosophy here being understood as the comprehension of human history. ${ }^{25}$

24 Marx, Karl, "German Ideology," Op Cit, p. 113-114.

25 There are Marxist thinkers who interpret the above passage as indicating that Marxist philosophy is founded on history, and not the pre-existing, material human-nature relations. Marx regarded history as a real generalization of the particular activities of living human beings in society; therefore history does not serve as the ontological basis of Marx's philosophic argumentation. History's specific, particular truths are based on physical facts of nature, so nature is not merely a static backdrop that can be ignored. For example, Sidney Hook, in accepting Marx's arguments concerning historical progress, considers the parallel to Aristotle in Marx's natural teleology as a "hangover" from Hegel's Naturephilosophy, rather than as an underlying fact of Marx's first theoretical 
As a presupposition of philosophy, the physical aspect of the immediate unity in human-nature relations is not considered worthy of investigation by Marx. Likewise, an investigation of the natural environment in which humans necessarily exist, is not relevant to philosophy, except insofar as to state the "first fact" that a necessary and material relationship exists. ${ }^{26}$ In other words, during the first stage of humanity's dialectical development, humanity, as the subject of philosophy or of self-conscious "man," doesn't exist; humanity isn't distinguishable from the rest of nature.

For Marx, history presupposes the subsistence level existence of the human species. History begins with a specific type of human activity; it begins with group activity that progressively and intentionally (i.e., historically or knowingly) modifies, or creates changes in, the "geological, orohydrographical, climatic" natural base (i.e., mining rock, damming rivers, throwing steam into the atmosphere, etc). It begins with the human species' production of the "means of subsistence" within the limits (or "conditions") imposed by the direct natural relationship.

Men can be distinguished from animals by consciousness, by religion or anything else you like. They themselves begin to distinguish themselves from animals as soon as they begin to produce their means of subsistence, a step which is conditioned by their physical organisation. ${ }^{27}$

premise. See also Mark Poster, especially Poster's defense of Sartre's interpretation of Marx's history-based ontology in his book, Foucault, Marxism \& History (Cambridge: Polity Press, 1984).

26 This presupposition is challenged by ecological philosophers, who, by definition, explore the problems "at the vast juncture between ... ecology and philosophy," and thus reexamine the concept of the human subject, in light of humanity's relationship to the environment.

27 Marx, Karl, “German Ideology," Op. Cit., p. 114. 
According to Marx, therefore, the activity of "production" is the defining characteristic of human beings in a historical context. As soon as "men" distinguish themselves "from animals" through the self-conscious group activity of production, the human species undergoes a transformation: "man" emerges from nature, understanding himself as separate from the other animals who also live on nature.

The simultaneous emergence of "man," via the human species' group act of intentional production, marks the beginning of the second stage of the dialectical development of humanity. The original immediate unity of human and non-human nature breaks down at the perceptual level ("humanity distinguishes itself"), and not at the actual level which persists in history as a restraint, or material need or condition of production (production as "conditioned by their physical organisation"). With the beginning of "production," the immediate unity of human beings with nature appears to dissolve, and the separation of "man" (as subject) from "nature" (as object) dominates humanity's understanding of the human/nature relationship.

With the emergence of history, when "men" first "produce their means of subsistence," or knowingly change the natural base in order to fulfill their needs, there also emerges a unity of fact and value, the co-existence of an empirical truth about human beings and the intrinsic value, or worthiness as an end in-itself, of human beings. Marx presents the case as follows ${ }^{28}$. It has already been established that, according to Marx, the Marx's discussion of the intrinsic value of human beings is brief, not well developed,
and not phrased in terms of "value." Marx's concept of "value" is narrowly associated
with "worth," in an economic sense, as was typical at that time. The conception of value
and valuation in a broad sense is part of a modern trend first fully articulated "in the
1890 's." In the more modern usage of the term "value," questions of value, both as worth
and 'what ought to be,' are grouped together in an effort to develop a theory of value and 
"first fact" is that man is a natural being, a being in direct unity with nature. However, "man" is also distinguished from animals and other natural beings because "man" is a "human" natural being. This peculiarly "human" attribute is that of intrinsic value: for Marx, the "human" characteristic of being is being-for-itself.

But man is not merely a natural being: he is a human natural being. That is to say, he is a being for himself. Therefore he is a species-being, and has to confirm and manifest himself as such both in his being and his knowing. ${ }^{29}$

In the above quote, Marx demonstrates that his understanding of human beings as ends, valuable for their own sake, follows the classical Greek (and Hegelian) association of wisdom with that which is pursued for its own sake. ${ }^{30}$ As a "species," man is an empirically existent natural being; as a human being, man is self-knowing and therefore is intrinsically valuable as a "being for himself." Living, as a process of confirming and manifesting oneself, unites non-human nature ("his being") with humanity (the intrinsically valuable, "being for himself" and self-conscious ("his knowing")). Therefore, it can be concluded that what is historically human, for Marx, is the intrinsic value which "man" brings to the natural activities required for staying alive. This attribute of activity, that of self-awareness and intrinsic value, is what separates production from the merely life sustaining activities of non-human natural beings.

valuation which includes "economics, ethics, aesthetics, jurisprudence, education, and perhaps even logic and epistemology;" Frankena, William K, "Value and Valuation," The Encyclopedia of Philosophy, Volume Eight, Op. Cit., p. 229.

29 Marx, Karl, "The Economic and Philosophic Manuscripts of 1844," Op. Cit., p. 337.

30 See discussion of the Greek conception of wisdom in Blanshard, Brad, "Wisdom," Encyclopedia of Philosophy, Vol 8., Op. Cit., pp. 322-323. 
Marx's claim that naturalism is distinct from both idealism and materialism is based on his understanding that first and foremost, human life activity is based on the direct unity of human and non-human nature; and second, human life activity is characterized by a theoretical awareness of the difference between human and non-human nature. On this basis, Marx's naturalism can be classified as a modern realist philosophy; that is, it is a philosophy which recognizes the independent existence of the material world with regard to human knowledge. ${ }^{31}$ Marx's naturalism is, therefore, opposed to all forms of idealism, i.e., those philosophic views which do consider the universe to be "dependent on mind or in some sense mental." ${ }^{\text {32 }}$ For Marx, although human beings cause history and create changes in nature, human beings did not materially create themselves or the rest of nature in the first place. Historically, "nature exists prior to man's transformative labor upon it;"33 logically, humanity exists in nature prior to the time when it "begins" to posit itself as "other" and distinct from other parts of non-human nature. By adding the element of "production" to the material human/nature relation of unity, Marx is asserting the primacy of human activity, of historically-situated living human beings, over eternally true ideas, whether these ideas are invoked to support an idealistic or materialistic conception of human reality.

Further, in demanding that philosophy assert the primacy of historically-situated human activity as the unity of theoretical activity in a direct and dependent relationship to material nature, Marx is also asserting that the unique and particular form of human

\footnotetext{
31 Hirst, R. J., "Realism," Encyclopedia of Philosophy, Vol. 7, Op. Cit., pp. 77.

32 Ibid., p. 77.

33 Parsons, Howard L., Op. Cit., pp. 10-11.
} 
activity in nature functions as the basis of philosophic abstraction. It has already been noted that Marx does not think that the particular details of the "naturism of man," or the analysis of the "geologic, orohydrographical ..." conditions in which humanity is immersed, are suitable subjects for philosophy. However, a characteristic feature of Marx's philosophy (especially his mature works) is his analysis of the particular details of the "humanism of nature," that is, an analysis of that aspect of productive activity which individuals "find" in existence and modify through labor.

The premises from which we begin are not arbitrary ones, not dogmas, but real premises from which abstraction can only be made in the imagination. They are the real individuals, their activity and the material conditions under which they live, both those which they find existing and those produced by their activity. These premises can thus be verified in a purely empirical way. ${ }^{\text {"34 }}$

Thus, the concrete and particular occurrences of life, the "real individuals" and "their activity and [the] material conditions," serve as the premises for philosophic analysis and abstraction. In Marx's turn to nature and active individuals, particular and unique realities form the basis of Marx's modified empirical, theoretical, analyses of the transformation of nature by labor.

From the above analysis, Marx can be understood as demanding that a) philosophers incorporate the procedures of empirical verification into their investigations in order to demonstrate the veracity of their concepts; b) living human beings serve as the basis for all abstractions and theorizing; and c) the social and natural reality created in history by labor be recognized as the appropriate subject of philosophy. Points "a)" and "b)" are the basis of Marx's naturalism as an approach to philosophy. Similarly, his naturalist turn to

34 Marx, Karl, "The German Ideology," Op. Cit., p. 113. 
human/nature unity as basis for philosophy serves as a model approach taken by Murray Bookchin, Karen Warren and Ame Naess, all of whom regard the establishment of concrete human experience as the founding premise for philosophy. However, there are major differences among these thinkers, and between them and Marx, with regard to the interpretation of the "human" aspect of the dynamic human/nature relationship (point “c"). Therefore, an analysis of Marx's concept of the process of human life activity (a.k.a. - production) is required in order to clarify some of the key issues which bind and separate Marx from Bookchin, Warren and Naess.

\section{The "humanism of nature:" the human transformation of nature.}

This section examines Marx's understanding of humanism as labor's dialectical transformation of nature. First, Marx's material, or rather "naturalist," transformation of the Hegelian dialectic of activity is examined. Second, it will be demonstrated, through an analysis of Marx's critique of Hegel's idealism, that Marx's version of the dialectic of history is based on the natural/human labor process which creates society and transforms nature. Third, several of Marx's historical examples of the human transformation, or humanism, of nature are reviewed, with particular attention paid to how Marx understands the value of nature. Together, these three points illustrate that Marx's understanding of the "humanism of nature" revolves around the laboring relationship of human beings, as conscious and intrinsically valuable individuals, to nature, with nature here understood historically as increasingly incorporated into human society. 
(i)

The grounding of philosophy in nature, or more specifically on the dialectical human/nature relationship, permeates the entire structure of Marx's philosophy. In an analysis of the Grundrisse, Carol Gould acknowledges the primacy of the opposition between "man" and "nature" in Marx's materialist version of the Hegelian dialectic: "Thus the primary sense of objectification for Marx is production, where the subject is in his terms 'humanity' and the object is 'nature." concept of the production of "the means of subsistence" requires an active, living human being involved in the externalization of him/herself in inorganic nature. Similarly, Marx's concept of the "humanism of nature" is a dialectical process of objectification (the realization one's being through the self-conscious and externally manifested positing of oneself in the "other"), which unites his naturalist understanding of human activity with the Hegelian dialectic of abstract mind. In order for Marx to demonstrate the natural basis of his version of the dialectic, he examines the process through which "human" and "nature" emerge as opposing aspects of labor and through which nature is historically transformed by human activity.

As an historical dialectic, the human and natural aspects of labor progress through three distinct stages of development (immediate unity, opposition and synthetic unity). As explained above, during the first stage of the dialectic of human activity, humanity did not exist for itself as "man" in contrast to "nature." Immediate unity is pre-historic. At

\footnotetext{
35 Gould, Carol C., Marx's Social Ontology, (Cambridge, MA: The MIT Press, 1978), p. 43.
} 
this stage, therefore, the process of life activity for the human species and for other organic life forms is the same: According to Marx

as a natural, corporeal, sensuous, objective being he ["man"]is a suffering, conditioned and limited creature, like animals and plants. That is to say, the objects of his instincts exist outside him... ${ }^{36}$

The terms "suffering," "conditioned" and "limited," refer to the external (or objective) satisfaction of needs. This immediate physical unity of humanity and non-human nature with regard to life sustaining activities contains the seeds of its own differentiation into opposites, which then form the beginnings of human history. The seeds of this perceptual differentiation are not physical; that is, in the immediate unity of human beings with nature, there exists an actual, particular characteristic (a mental characteristic) that is unique to humanity. In defining humanity as distinct from plants and animals, all of whom are "conditioned and limited" by their natural needs, Marx indicates that only humanity is "suffering;" that is to say, only humanity is intellectually and emotionally conscious of experiencing the physical conditions and limitations created by the fact that the satisfaction of essential human needs is fulfilled objectively in nature. ${ }^{37}$ Thus, according to Marx, survival level activity, the direct link of the human species as part of nature, is the condition of immediate unity from which the conscious, or self-conscious, component of the dialectical process of objectification emerges, thereby intemally generating the opposition between man as subject and nature as object. ${ }^{38}$

36 Marx, Karl, "The Economic and Philosophic Manuscripts of 1844," Op. Cit., p. 336.

37 McClellan, David, The Young Hegelians and Karl Marx, (London: Macmillan and Co. Ltd., 1969), pp. 107-108.

38 Bookchin, Warren and Naess all consider Marx's failure to explore the motivation or origin of human self-consciousness as problematic with regard to the formulation of a natural-based, realistic ethics. Implicitly Marx's failure is addressed by each of them 
For Marx, then, the second stage of the dialectical development of human activity has its origins in nature. From a natural base, Marx's philosophy prioritizes the activity of living, human beings over the activity of Absolute Mind. Gould recognizes that Marx offers a materialist relocation of the Hegelian dialectic.

Further, in distinction from Hegel, Marx sees the dialectic of social development not as a series of stages in the development of the Idea, that is as a dialectic of thought, but rather as one generated by the actions of real, concretely existing individuals. In this respect Marx gives ontological priority to such active existing individuals, ... ${ }^{39}$

Marx's analysis of the second stage of dialectical development, then, as a 'mediated unity' or objectified unity in which human activity changes both nature and "man," can be understood as a humanist reworking of Hegel's dialectic of abstract activity.

Marx's reworking of the Hegelian dialectic can be viewed as part of his attempt to eliminate abstract thought as the basis of philosophy. In the brief section that follows, Marx's critique of Hegel's idealistic version of the process of objectification is reviewed in order to illustrate how Marx grounds the origin of the dialectical tension in nature rather than in Spirit.

through the development of concepts concerning the relation between autonomous human consciousness and nature. In an explicit discussion of this topic, Max Scheler notes Marx's "legitimate opposition to the classical theory" of spirit, in which the idea is an autonomous, creative power, is marred by its total lack of recognition of any autonomy of spirit. Thus, according to Scheler, Marx's productive, labor-based, social conception of intrinsic value is incapable of supporting the formulation of an ethic. For discussion, see Scheler, Max, Man's Place In Nature, translated by Meyerhoff, Hans (New York: The Noonday Press, 1971), pp. 36-40 and 62-63.

39 Gould, Carol, Op. Cit., p. 28. 
The key to Hegel's greatness, in Marx's opinion, is his discovery that labor is an active dialectical process of objectification. For Marx, labor is a process of "self-creation:" "man," through the activity of human labor (understood as a process by which objects external to man become "man's inorganic body"), changes the natural base: "man" changes "his circumstances" and thereby changes (or creates) himself. Through this process of objectification, which causes changes according to the principle of the "dialectic of negativity," "man" goes through a historical transition from a merely natural being to a "real" (fully actualized) human being. This process, which Hegel recognized in an idealistic form, is the one by which the activity of labor creates "real man," as the naturo-historical human being who has fully manifested himself in the external world.

The outstanding achievement of Hegel's Phanomenologie and its final outcome, the dialectic of negativity as the moving and generating principle, is thus that Hegel conceives the self-creation of man as a process, conceives objectification as the loss of the object, as alienation and as transcendence of this alienation; that he thus grasps the essence of labor and comprehends objective man - true, because real man - as the outcome of man's own labor. ${ }^{41}$

Thus, in the passage above, Marx acknowledges his acceptance of Hegel's 'dialectic of negativity.' Yet, in contrast to Hegel, Marx's historical-dialectical process of labor is

40 The "dialectic of negativity" is an aspect of the dialectical method, the critical aspect that " "produces movement which makes history" due to the mental process of abstraction in which humans posit " $\mathrm{X}$ " (Being, capital, nature, humanity etc.) as a general category (a universal) distinct from, or in opposition to, " $x$ " as a particular thing. The abstract aspect of the human activity of self-objectification in nature is, in Hegel's words, a "'negative self-relation; in other words it draws a distinction between it and itself." For discussion, see MacGregor, David, The Communist Ideal in Hegel and Marx, (Toronto: University of Toronto Press, 1984), pp. 160-163 and 244-246.

4t Marx, "Economic and Philosophic Manuscripts of 1844," Op. Cit., pp. 332-333. 
based on nature and the power of human life activity, not on the power of the activity of Abstract Mind.

Marx's critique of Hegel is not restricted to the process of labor as the creation of objective man; it also extends to the dialectical history of society and to labor's transformation of nature. For Marx, humanity has a laboring or productive relation to nature, through which nature acquires a "human character" (i.e., nature is understood, used and valued by human and is physically transformed into products for human use).

According to Marx, Hegel commits two "error[s]" with regard to his understanding of the activity of labor.

There is a double error in Hegel.

The first... When, for instance, wealth, state power, etc., are understood by Hegel as entities estranged from the human being, this only happens in their form as thoughts... ... The whole history of the alienation process and the whole process of the retraction of the alienation is therefore nothing but the history of the production of abstract (i.e., absolute) ||XVI| thought - of logical, speculative thought. ${ }^{42}$

Hegel's second error concerns the continuous transformation, or process of "self-creation," of the world.

In the second place: the vindication of the objective world for man ... The human character of nature and of the nature created by history - man's products - appears in the form that they are the products of abstract mind, and as such phases of mind thought-entities. ${ }^{43}$

The creation of products from nature is understood by Hegel as a result of abstract activity (of the "thinking mind") rather than of naturo-historical activity (of the laboring

\footnotetext{
$42 \quad$ Ibid., p. 331.

$43 \quad$ Ibid., p. 332.
} 
human being). So, for Marx, the objective world of nature (in its pristine state or as the end product of a social industrial process) is, like society, a historical result of the human activity of labor, where human is understood as integrated by definition with nature.

To fully understand Marx's phrase, "human character of nature and of the nature created by history," the dialectical process of labor which transforms nature needs to be examined. This process begins simultaneously with the "humanism of nature" in history as humanity"s first attempts at "producing their means of subsistence" and continues through to capitalism; it ends with communism. Marx defines communism as the attainment of a state in which all of humanity is naturalized - humanity expresses itself in all of nature and in which all of nature is humanized - all of nature is transformed by labor. This full development of the relations between human and non-human nature implies an overcoming of the dialectical opposition and its yielding to a new stage of synthetic unity and harmony.

This communism as fully developed naturalism, equals humanism, and as fully developed humanism equals naturalism; it is the genuine resolution of the conflict between man and nature and between man and man. ${ }^{44}$

Marx's discussion of human-nature relations during the second stage of the dialectic, when the opposition between "man" and "nature" is the main tension in the labor process, reveals his understanding of the phrase the "human character of nature" and the basis for his economic conception of value.

4 Marx, Karl, "Economic and Philosophic Manuscripts of 1844," Op. Cit, p. 296. 
In order for humanity to impart its character to nature, the distinctly human characteristics, that of the self-conscious separation from nature and the intrinsic value of being human, must co-mingle with non-human nature. The term "mediation of labor" describes this co-mingling or interpenetration of opposites in a single direction from humanity to nature. It is the application of human knowledge to the human/nature relation, an active process that introduces the human quality of intrinsic value, of existing as an end in itself, into inorganic nature. Literally, the human feature of being intrinsically valuable passes into nature. This passage of intrinsic value from human beings into nature through the socio-historical process of production comprises the second stage of the dialectic of human/nature relations. The process encompasses the history of the becoming of Communism, from the first self-conscious acts of production marking the beginning of the history of "man" through to the overcoming of Capitalism. Thus, the "humanism of nature" is the value of nature; and the extent of the "humanism of nature" is the extent to which human labor has made nature valuable - in an economic sense of bringing nature into the social fabric of exchange.

The association of intrinsic value with Marx's economistic use of the term "value" is implied by the sharp distinction he draws between the utility of nature and the value of nature when "mediated by labor." Nature has "use-value 45 " (i.e. utility), but no value (i.e. intrinsic or instrumental worth) without the input of labor.

A thing can be a use-value without being a value. This is the case whenever its utility to man is not mediated through labour. Air,

\footnotetext{
45 Marx's use of the term "use-value" in this case introduces a confusion, as he clearly indicates in the following quote that no "value" is present. The thing referenced is merely of "use."
} 
virgin soil, natural meadows, unplanted forests, etc. fall into this category.46

In order to demonstrate empirically that the "humanism of nature" is the intrinsic value of "man" objectified in "nature," Marx analyzes the particular details of historically real examples of things (land, money and women ${ }^{47}$ ) which are objects of human need. The "human" aspect of the dual (human/nature) character of the products of nature is obscured under the capitalist mode of commodity production, the mode of production in which the historically growing perception of nature and humanity as mutually exclusive is extreme. Marx combats this perception by arguing that the unity of humanity and nature is revealed through an analysis of value and objective need. It should be noted that value, for Marx, is linked directly with objective needs; and therefore it assumes the perception of a subject-object division that characterizes stage two of the dialectical relation between human beings and nature. Marx does not discuss value in relation to the pre-historical, subsistence (animal-like) existence of the human species.

Marx's concept of value, as the analysis of his three examples shows, is based upon the differentiation of value into two united, yet distinct aspects, that of intrinsic value and utility. For Marx, intrinsic value is associated only with the self-conscious, productive activity of human beings. Human activity is the only good which is valuable in and of itself; and historically, labor is the human activity which creates value in nature. Therefore, historical nature, as the product of human activity, has value because it is an

\footnotetext{
46 Marx, Capital, Op. Cit., p. 131.

47 Women, while not "things," are treated in a thing-like manner with regard to their being an "object" of need. The "subjectivity" of women is not meant to be excluded in this example.
} 
intrinsic good, although only to the extent that it has been modified or created by labor. Also, for Marx, the utility of things objectified by "man" is a historical process in which "use-values" (things untouched by human labor and hence valueless) become things possessing instrumental values (things modified by, and hence containing, the intrinsic value of human labor). Thus, the following examples of Marx's analyses of value and objects of human need reveal the unity of human/nature relations from a humanist viewpoint through the recognition of intrinsic value of nature - in the form of social exchange value based on human labor. At the same time, they reveal the unity of human/nature relations from a naturalist viewpoint through the recognition of instrumental value and use value, wherein a thing is perceived as merely useful in satisfying a human need.

The first of Marx's examples concerning the process in which the productivity of labor transforms part of nature involves the cultivation of land. Virgin soil (useful, but not of "value") comes under plow and is transformed into farmland (an economically valuable thing in any human society whose members are capable of distinguishing virgin from non-virgin soil, and hence perceiving nature objectively). As farmland, the soil now has instrumental value. The "value" component of the soil's instrumentality is dependent upon the intrinsic value of human labor. As farmland, the intrinsically valuable part of nature is the part of nature that "man" takes as his "inorganic body," an extension of his being in an external world. Farmland, as opposed to virgin soil, thus has value. This type of usefulness is termed "instrumental value" by Marx because it is both instrumental in (or useful as a means for) satisfying human objective needs and valuable because is 
possesses characteristics by virtue of its transformation by human labor (labor being an intrinsic good). The intrinsic value of historical nature and of commodities is not recognized under relations associated with the capitalist mode of production, wherein the "primary value of nature is its instrumental value in the production of economic goods." Instrumental value, like "use-value," posits nature as a resource available for human use and/or exploitation. Thus, the transformed products of nature, a mere commodity with only a material (inactive or factual) existence, actually possess value, even if only in the form of instrumental value, which is in turn dependent upon human beings objectifying themselves in nature and therefore is dependent upon the extension of intrinsic value into nature.

The second example of the "humanism of nature" and the "naturalism of man" concerns the transformation of metal into money. A helpful examination of the unity of nature and value in the case of an abstract product, money, occurs in the Grundrisse. In this case, gold has a dual character. First, it is, in fact, a natural object, part of inorganic nature; and therefore linked to humanity through the "naturism of man." Second, it is a social product; part of human society in its character as the symbolic form of exchange value and the quantitative form of labor value. In the second sense of being money, gold is humanized nature. Although nature may be more difficult to see after undergoing uni-directional change via human hands, nature is the material upon which, and with which, man exercises his powers. Clearly, inorganic nature is part of money; yet money is also a social relation:

48 Karen Warren, "Introduction: Part III: Ecofeminism," in Radical Environmentalism: Philosophy and Tactics by Peter C. List, p. 255. 
Gold and silver, in and of themselves, are not money. Nature does not produce money, any more than it produces a rate of exchange or a banker. ... To be money is not a natural attribute of gold and silver, and is therefore quite unknown to the physicist, chemist etc. as such. But money is directly gold and silver. ${ }^{49}$

In money, then, the two phases of dialectical development are simultaneously existing, an original unity (i.e. product of nature) and a mediated unity (i.e. product of labor) with human attributes of exchange value created through the historical process of objectification. The human attribute dominates, as the most obvious characteristic of gold coin in economic circulation is the fact that it is money.

The third type of transformation involves people: the case wherein the object of use and need fulfillment is another human being (i.e., the proletariat, the slave, the female, respectively, fill the needs of the capitalist, the master, the male). In the case of humans objectifying other humans, the unity of the material facts of nature and intrinsic value of humanity is most clearly expressed in male-female relations. Marx pays scant attention to male-female relations. His analysis of these relations in "The Economic and Philosophic Manuscripts of 1844," however, is of particular interest in that it does not neatly conform to the pre-social/pre-historical, historical and communist stages of economic development. Furthermore, both Murray Bookchin and Karen Warren return to the historical origin of male-female social relations as a point of departure for integrating the foundations of a nature-based ethic into value theory, ${ }^{50}$ thus abandoning Marx's historical and labor based conception of value and ethics.

49 Marx, Karl, Grundrisse, Op. Cit., p. 239.

50 Naess takes a completely different approach; one that is more in line with Scheler's critique of the naturalist theory of Marx. 
In Marx's analysis of marriage and male-female relations, he clearly indicates that the unity of humanity with nature is a fact of life in all stages of the dialectic. This unity is trans-historical, although always manifested in a particular forms. At the animal-like, subsistence-level (the first stage of the dialectic), male-female relations are necessary and are part of humanity's immediate relation with nature.

The direct, natural and necessary relation of person to person is the relation of man to woman. In this natural species-relationship man's relation to nature is immediately his relation to man, just as his relation to man is immediately his relation to nature - his own natural destination. ${ }^{51}$

This immediate relation precludes objectification, and, therefore, is not a value relation. Human beings, as ends in themselves and as intrinsically valuable beings, do not exist at this stage of development. Neither is the male-female relationship, in its immediate unity with nature, an ethical relationship. Rather, for Marx, it is a relationship of necessity and destiny. By implication, we can conclude that Marx, at most, regarded pre-historical male and female members of the human species as "suffering" creatures, and, therefore, at least possessing some degree of emotional consciousness distinct from non-human animal awareness. It is this pre-social, emotional consciousness that Bookchin and Warren explore as the source of ethical sensibility and of a peculiarly female perspective, respectively.

Ethical human relations and the instrumental value of nature are part of male-female relations throughout the historical phases of property development, as well as into the early communist phase of the dialectic (represented by the call for the abolition of private

s1 Marx, Karl, "Economic and Philosophic Manuscripts of 1844," Op. Cit., p. 295. 
property and marriage). In these dialectical stages of maie-female relations, Marx's understanding of the intrinsic value of humanity as objectified in nature is directly expressed as equating to the humanization of nature and the naturalization of humanity. While ethical discussion is limited to Marx's moral judgments concerning the "degradation" of man with regard to "the approach to woman as the spoil and handmaid of communal lust," the analysis of the instrumental value of one human being to another contains Marx's recognition of the unity of both instrumental and intrinsic value, along with that of nature and humanity.

From the character of this relationship follows how much man as a species-being, as man, has come to be himself and to comprehend himself; the relation of man to woman is the most natural relation of human being to human being. It therefore reveals the extent to which man's natural behavior becomes human, or the extent to which the human essence in him has become a natural essence the extent to which his human nature has come to be natural to him. This relationship also reveals the extent to which man's need has become a human need; the extent to which, therefore, the other person as a person has become for him a need — the extent to which he in his individual existence is at the same time a social being. ${ }^{52}$

This unity of the value of humanity and that of nature, like the unity of humanity and nature, is based upon Marx's concept of the historically progressive, self-conscious integration of humanity with nature through the objective fulfillment of needs (i.e., though labor). As women and men transform themselves from merely natural beings into human beings in a social process, their relationship parallels 1) the extension of intrinsically valuable human beings into nature (i.e. naturalized humanity), via the

${ }^{52}$ Marx, Karl, "Economic and Philosophic Manuscripts of 1844," Op. Cit., p. 296. 
intrinsic value of labor; and 2) the creation of an instrumentally valuable (i.e. humanized) nature.

From these three examples concerning land, money and women, it can be stated that Marx's understanding of the role of labor in the transformation of nature recognizes the intrinsic value of nature in the products and social institutions of capitalism. Further, even though this value is predominately manifested in the form of instrumental value, the complete "humanism of nature" holds out the future possibility that once humanity completely objectifies itself in nature, the "brutish" relation of use will yield to a harmonious relation that allows for the harmonious and synthetic unity of human beings and nature.

Conclusion: It has been demonstrated that Marx's understanding of human/nature unity underlies the material-humanist metaphysical foundations of Marx's philosophy, his critique of idealism and consequent demand that philosophic premises rest on the concrete, details of real life experience, rather than on religious, philosophic or scientific theories. His naturalist/humanist approach to philosophy serves as a model for philosophers in the modem realist tradition, including Bookchin, Warren and Naess. Further, Marx's view of nature incorporates the intangible world of the historical, social reality created by living human beings into the base of 'verifiable' knowledge (i.e. knowledge of physical and material matter), marking his position as distinct from pure scientific empiricism, which restricts itself to propositions and abstract facts and excludes human experience. This abandonment of a dualist understanding of the concepts of 
human/nature, mind/body and fact/value also plays a prominent role in Bookchin's, Warren's and Naess's conception of human/nature relations.

In Marx's conception of a naturalism that equals humanism and a "humanism [that] equals naturalism," humans dominate (or define) the relationship. Humanity is active, while nature changes only insofar as nature is acted upon by humans. While neither Bookchin, nor Warren nor Naess challenges the idea that human self-consciousness permeates the concept of human/nature unity, they do question Marx's claim that human self-consciousness (i.e. defined by Marx as the ability to abstract from or objectify a situation), mixed with nature in the process of production, adequately defines the human/nature relationship. All three philosophers agree that Marx's understanding of the intrinsic value nature as indirect, as a function of human labor's creation of instrumental value in nature, is an inadequate basis for the articulation of an ethical relation between human and non-human nature.

The next three chapters demonstrate the debt that Bookchin, Warren and Naess owe to Marx's humanist/naturalist view of human/nature relations. Each chapter also emphasizes those aspects of their respective philosophies which branch off from the realist foundation that Marx erected, and does so in order to develop a conception of the concretely-real and dynamic human/nature relationship which also incorporates, or supports, ethics. 
CHAPTER 2: BOOKCHIN: NATURE AS THE SOURCE OF CONSCIOUSNESS

"Social Ecology," a field of study first advanced by Murray Bookchin, may also be characterized as "dialectical naturalism. ${ }^{53 "}$ The use of the terms "dialectical naturalism" and "social ecology" to describe Bookchin's philosophy is indicative of his understanding of human society as part of the process of the dialectical development of nature - or more specifically (and like Marx), of the dialectical development of human consciousness from within nature. Although Bookchin's dialectical view of nature is not "Marxist," his debt to Marxism and his "earlier commitment to socialist orthodoxies of all forms"s4 is evident in his approach to philosophy as a dialectical development of society that is grounded in nature. A key difference between Marx and Bookchin is Bookchin's rejection of humanism (and of humanism's equation with naturalism by Marx). For Marx, the central focus of the material dialectic is human beings (in a socio-natural, historical context), while for Bookchin, the central focus of the material dialectic is nature (in a socio-natural, historical context). This difference in orientation leads to major differences in the structure of the dialectic and in the conceptualization of what Marx termed the human aspect of the dialectic, which involved relationships between human consciousness, human activity, non-human nature and value.

This chapter shows that Murray Bookchin 1) reworks Marx's conception of historic dialectic so as provide a pre-human, evolutionary foundation for human consciousness in nature, a topic which Marx did not address; and, in so doing 2) arrives at a broader

53 John Clark, "Introduction, Part Four: Social Ecology," Environmental Philosophy, (Englewood Cliffs, New Jersey: Prentice-Hall, Inc., 1993) pp. 345.

54 Bookchin, Murray, The Ecology of Freedom, (Pal Alto, California: Cheshire Books, 1982), p. 31. 
conception of the role of nature in the dialectic of historical development than did Marx. In analyzing Bookchin's reconception of the historical dialectic, it will be demonstrated that Bookchin replaces Marx's notion that the perception of the dialectical tension between "man" and "nature" originates in human productive activity, with the notion that this tension originates in the activity of human consciousness. ${ }^{55}$ Also, this chapter explores Bookchin's dialectical understanding of the activity of human consciousness ${ }^{56}$ : it examines his claim that the two antithetical aspects of human consciousness which evolve from nature are "sensibility," a term that characterizes the intuitive, ethical aspect of human consciousness, and "consciousness," a term that characterizes the analytical aspect of human consciousness.

1. Bookchin's material dialectic of the activity of consciousness - The purpose of this section is to demonstrate that Bookchin, while modeling himself on Marx's material realism, modifies Marx's dialectic, shifting the focus of the dialectical tension in stage two of Marx's dialectic from human productive activity in an economic sense to the activity of human consciousness. It will be shown that although Bookchin and Marx

55 "Perhaps one of social ecology's most important contributions to the current ecological discussion is the view that the basic problems which pit society against nature emerge from within social development itself - not between society and nature." Bookchin, Murray, "Society and Ecology," Remaking Society, (Boston, MA: The South End Press, 1990), p. 32.

56 Bookchin's terminology is a little inconsistent, but his concept of a developing self-consciousness in nature that has both ethical/intuitive and analytical aspects is the same throughout the changes in terms. Sometimes, he uses the terms "consciousness" and "reason" as umbrella terms, which describe both aspects of the dialectic. See for example, pp. 38 and 304, respectively of The Ecology of Freedom, Op. Cit. (also cited in this paper, see below). At other times, the term "consciousness" refers to humanity's capacity for analytical or abstract thinking. See The Ecology of Freedom, p. 19 or footnote 62 of this paper. 
agree on the physical aspect of human/nature unity, their conceptions of the consciousness (or "human" aspect of human/nature unity) differ substantially. Marx understands directed, self-conscious activity as a human characteristic that is continuously influenced by (and does not exist without) its physical interaction with and material dependence upon nature. Bookchin regards directed, self-conscious activity as a characteristic of nature that reaches its highest stage of development in human consciousness.

In distinction from Marx, Bookchin sees the dialectic of social ecological development not as a series of stages in the development of humanity, that is, a dialectic of human activity, but rather as a series of stages generated by nature's real and concretely developing potential for consciousness. ${ }^{57}$ For Bookchin, "consciousness, the teleological end of nature, is self-creating and humanity is its highest expression." 58

For Bookchin, the fully developed consciousness of nature is not existent in all of nature (a position which Bookchin would be the first to declare as anthropomorphic or part of the misguided Eastern philosophy of 'cosmic oneness.') ${ }^{59}$ Rather, Bookchin understands the consciousness of nature as a dialectical process in which nature actualizes its own potential for self-consciousness through the activity of evolution.

57 This sentence is a paraphrase of Carol Gould's description of Marx's adaptation of Hegel's dialectic. See Footnote 37, p. 16, Chapter 1 of this paper.

s8 Bookchin, Murray, The Ecology of Freedom, Op. Cit., p. 38.

59 "May we not reasonably ask why the natural world has to be peopled with earth gods and goddesses when natural evolution exhibits a marvelous power of its own to generate such a rich and wondrous variety of living beings? ... Is it not the crudest form of 'anthropocentrism' (to use a word for the projection of the human into the natural that evokes so much disdain in ecology movements) to introduce deified forms created by the human imagination into the natural world in the name of ecological "spirituality?"' Bookchin, Remaking Society, Op. Cit., pp. 12-13. 
In the passage below, Bookchin demonstrates his agreement with Marx's

historical-materialist approach to history.

Until very recently, human society developed around the brute issues posed by unavoidable material scarcity and their subjective counterparts in denial, renunciation and guilt. The great historic splits that destroyed early organic societies, dividing man from nature and man from man, had their origins in the problems of survival, in problems that involved the mere maintenance of human existence. Material scarcity provided the historic rationale for the development of the patriarchal family, private property, class domination and the state. ${ }^{60}$

Within limits, Bookchin confirms his acceptance of Marx's predominately instrumentalist view of human/nature relations ${ }^{6]}$ during the course of human history:

Since the rise of patriarchy, humanity has used non-human nature to survive and dominant groups within human society have used other human beings to satisfy their objective, natural needs.

For Marx, the dialectic of history was a material one, having sprung from the physical unity of human beings with nature. From that "natural base" human social relations, in interaction with nature, developed into an antithesis based on the material conditions and

61] Bookchin, Murray, Post-Scarcity Anarchism, (Berkeley, California: Ramparts Press, Inc.) 1971 , p. 9.

61 Bookchin interprets Marx through the Orthodox Marxist tradition, which holds that Marx's emphasis on material relations indicates his exclusion of non-material aspects of human consciousness and activity. (A position challenged in Chapter One: see claim that Marx is not strictly empirical, p. 25) Under the Orthodox interpretation, "material scarcity provide[s] the historic rationale," and Marx's philosophy begins with historical interpretation. However, this interpretation differs from the one presented in Chapter One, wherein Marx merely isolated material need as natural need. Labor, understood as human activity in broad sense, includes the development of language, religion and culture and is more than mere economic 'production relations'. See Marx, Karl, The German Ideology, Op. Cit. Discrepancies among the various interpretations of Marx's early works of philosophy is not the subject of this thesis. 
activity (activity for survival) of human beings. Bookchin deviates from this Marxist, labor-based conception of the dialectic in history in two ways.

First, Bookchin expands the time frame of human history, beginning philosophical analysis of human life at a time before the human opposition with nature occurred (that is, during Marx's stage of unity between "man" and "nature"). By contrast, Marx begins human history and philosophical analysis with the human/nature opposition in the second stage of self-conscious, perceived production. For Bookchin, the human subject exists as subject prior to what Marx considers as the emergence of humanity.

Second, Bookchin regards the future transition to the third and highest stage of dialectical development to be contingent upon changes in human consciousness, instead of upon changes wrought by human labor as it moves from Marx's capitalist to communist stage. Bookchin, unlike Marx, locates the origins of society in "early organic" human communities that existed prior to any split in opposition to nature. Bookchin's reference to the "great historic splits that destroyed early organic societies" indicates that he understands societies, and therefore human history, to have existed as human societies prior to the occurrence of divisions that stemmed from material conditions and property relations of domination. Therefore, for Bookchin, self-conscious material activity is not necessarily linked to a dialectical opposition to nature and to labor, as it is for Marx. From this germ of an idea, Bookchin's analyzes "early organic societies" in search of the material source of a dialectical development in society which encompasses the value of harmony with nature. He does so by reworking Marx's own analysis. 
Although their [preliterate peoples] logical operations may be identical to ours formally, their values differ from ours qualitatively. The further back we go to communities that lack economic classes and a political State communities that might well be called organic societies because of their intense solidarity internally and with the nature world - the greater evidence we find of an outlook toward life that visualized people, things, and relations in terms of their uniqueness rather than their 'superiority' or 'inferiority. ${ }^{32}$

In contrast to Marx, Bookchin asserts that not only the physical aspect of humanity's direct unity with nature is carried forward into society, but humanity's consciousness has a direct link with nature, at an ethical level and not merely at a productive one. Furthermore, while Marx only considers the impact of human activity on nature, and humanity's ability to impart value to nature, Bookchin considers the impact of natural activity on humanity ${ }^{63}$ and claims that nature has the ability to impart value to humanity.

Marx tried to root humanity's identity and self-discovery in its productive interaction with nature. But I must add that not only does humanity place its imprint on the natural world and transform it, but also nature places its imprint on the human world and transforms it. ${ }^{\text {G- }}$

In addition, Bookchin regards consciousness, not material conditions, as the key to ushering in the post-capitalist phase of the historical, dialectical transition. He seeks to reinterpret Marx's material dialectic because the material abundance of capitalism, and the Soviet experiment with communism, did not lead to a state of harmonious human-nature or of human-human relations, as predicted for the third stage of communism by Marx. Bookchin argues that if the material activity of production drove

\footnotetext{
62 Bookchin, Murray, The Ecologv of Freedom, Op. Cit., p. 44.

${ }^{63}$ See discussion, Chapter One, page 20, regarding the single direction

or source of activity yielding the penetration of value and human self-consciousness into nature.

of Ibid., p. 32.
} 
society, then surely the material abundance of today would have already brought us to a culture of freedom and harmony. The possibility of there being enough material wealth for everyone, which Marx held to be a possibility of the imminent future, has, according to Bookchin, arrived. Bookchin's rejection of Marx's predictions about communism and its attendant harmony of humanity and nature, then, is based on a realistic assessment of twentieth century technological capacities and social failures.

We of this century have finally opened the prospect of material abundance for all to enjoy - a sufficiency in the means of life without the need for grinding day-to-day toil. We have discovered resources, both for man and industry, that were totally unknown a generation ago. ... In short, for the first time in history we stand on the threshold of a post-scarcity society. ${ }^{63}$

Thus, in these two ways, by revising Marx's concept of the origins of human self-conscious history and by rejecting communism, Bookchin establishes his acceptance of a material-historic dialectic in history, while rejecting an understanding of dialectics based on material relations of production. Recall that for Marx, the first stage of the dialectic is an immediate human/nature unity in which human activity is characterized by animal-like, survival level activities of the human species. The movement in the second stage, in which humans perceive themselves in opposition to nature, is a result of the process of self-conscious objectification and the social activity of production. This activity yields the third stage, communism, a self-conscious unity of humanity and nature. In contrast, Bookchin's dialectical stages progress due to the activity of consciousness, not the activity of labor. Bookchin's first stage is one of human/nature immediately unity, which includes a basic human social consciousness in the form of communal

6s Bookchin, Murray, Post-Scarcity Anarchism, Op. Cit., p. 10. 
ethical sensibility - a consciousness that has historically evolved from non-human nature. Bookchin's second stage is marked by the evolution of abstract consciousness, as evidenced through the rise of abstract society (institutions) and the perception of human/nature opposition. Bookchin's third stage is characterized by the synthetic unity of (or overcoming of the opposition between) ethical sensibility and abstract reason, leading to the emergence of ethical institutions in a society that recognizes itself as natural and therefore self-consciously harmonizes itself with nature.

If society ${ }^{66}$ isn't realizing the benefits of material wealth for the purpose of freeing humanity and nature from social oppression, then what is holding society back from the historic dialectical transition into Marx's third stage of synthetic unity?

What we crucially lack is the consciousness and sensibility that will help us achieve such eminently desirable goals - a consciousness and sensibility far broader than customarily meant by these terms. $^{67}$

For Bookchin, the transition to a harmonious "post-scarcity society" requires the unity of two opposing aspects (sensibility and consciousness) of the evolving naturo-social dialectic of consciousness. Society already has the material means to change, so now all it needs is the "consciousness and sensibility" to change. Marx's understanding of the culmination of the dialectic through the production of the material means for overcoming need in society is wrong. Bookchin, therefore, asserts that the dialectic which will

\footnotetext{
66 "Society" here refers to capitalist society. Bookchin does offer a critique of Soviet economies as well; however, this discussion is not taken up here.

67 Bookchin, Murray, The Ecology of Freedom, Op. Cit., p. 19. Also, in Post-Scarcity Anarchism, an earlier version of this concept is described in psychological terms. For example: "[T] recesses of the "privileged" man's psyche are fair game for exploitation and domination." Post-Scarcity Anarchism, Op. Cit., pp. 11 -12.
} 
culminate in a harmony between human society and nature, and which will overcome the human dominance of other humans through hierarchical social institutions, is not one that centers on human productive activity, but one that emphasizes nature's activity of self-consciousness, expressed in an opposition between human social consciousness (abstract thought) and natural sensibility (ethical sentiment). For Bookchin, understanding the natural activity of the mind, and the opposition within human consciousness, is key to understanding the overcoming contemporary oppression. ${ }^{68}$

Although Bookchin's central concem is with the human ability to conceive of a different type of society (and take action accordingly), he does not reject the materialism of Marx's reconception of empiricism. Recall that Marx pronounces the premises from which philosophy begins to be social facts, based on living human beings and their interactions with material conditions of life. In this way, he asserts the materiality of his conception of consciousness, and Bookchin does not disagree. Bookchin's understanding of the coming social transformation, while not based on the historic role of the proletariat, is not, like Hegel's understanding of consciousness in history, grounded in an abstract notion or religious conception of the dialectic of mind. The conflict between a dominating, rational society and the idea of a harmonious, ethical society is based on a real conflict of consciousness as manifested in society.

Running through the nightmare of domination [of both human beings and nature within a hierarchical society] is the vision of

\footnotetext{
${ }_{68}$ This critique of capitalist society as lacking in the social consciousness required to overcome oppression is also levelled against communist societies: "Marx's vision notwithstanding, what tends to 'wither away' after this kind of 'revolution' is not the state but the very consciousness of domination." Bookchin, Murray, Post-Scarcity Anarchism, Op. Cit., p. 13.
} 
freedom, the repressed intuition that what-is could be otherwise if abundance were used for human ends. ${ }^{.9}$

Let there be no mistaken notion that this tension [between "what-is" and "what-could-be"] floats in some vague fashion between theoretical abstractions. The tension is real, and it finds daily expression in the lives of millions. ${ }^{70}$

Thus, Bookchin accepts a material dialectic ${ }^{71}$ in history, but one that is based on changes in human consciousness in addition to the direction of human physical activity. Furthermore, Bookchin's central dialectic is one of a material or natural consciousness that has ethical/intuitive and analytical/abstract components. Recall that for Marx, the first dialectical stage, that of immediate human/nature unity, contains the seeds of the opposition in the particular trait of suffering - a trait that emerges prior to human self-conscious activity. The second stage, characterized by self-conscious material activity (objectification), emerged from the first to yield the perception of a human/nature opposition. The third stage is reached through labor, which in the second stage starts and finishes the task self-consciously integrating humanity with nature. Thus, for Marx, the second stage conflict between man and nature dissolves into a self-conscious synthetic unity. For Bookchin, the first stage of the dialectic, that of immediate human/nature unity, is characterized by one aspect of the dialectical conflict that emerges in stage two: stage one is characterized by human consciousness (as the 'sensibility' of peoples in

\footnotetext{
69 Ibid., p. 12.

Ibid., p. 14.

"Indeed, how should we think out these questions: By means of conventional logic? Intuition? Divine inspiration? Or, perhaps, by developmental ways of thinking that are called "dialectical?"” Bookchin, Murray, Remaking Society, Op. Cit., p. 17.
} 
organic society) with nature. The second stage of the dialectic is characterized by the development of abstract human consciousness (and social institutions ${ }^{72}$ ) that opposes the ethical sensibility of humanity toward nature. Thus, for Bookchin, the resolution of the dialectical conflict in the third stage is not a synthesis of the material conflict of stage two human/nature opposition (as it is for Marx). Rather it is a resolution of the conflict between stage one ("what-could-be," as it was in the past) and stage two ("what-is") consciousness. In these ways, Bookchin broadens the scope of Marx's dialectic, grappling with the issue of "consciousness," which Marx left relatively unexplored other than as a key aspect of productive activity.

\section{Bookchin's concept of the development of human consciousness from nature} Bookchin rethinks the connections between human socjety and nature to explain how human consciousness evolves from nature. This section illuminates what Bookchin takes to be the physical relationship between society and nature, in the form of links between human sensibility and human behaviors that are rooted in nature. It reviews how the dialectical process (a 3-stage development from original unity, to opposition, and finally to reconciliation or synthetic unity) is manifested through the development of human consciousness in society. Differences between Bookchin's and Marx's conception of the historical dialectical development of consciousness in nature are highlighted. This

72 These institutions happen to be hierarchical institutions of domination. Although Bookchin traces their development, he cannot (and admits that he cannot) really explain why this occurred. The occurrence of the development of these institutions which dominate nature, however, justifies the dialectical interpretation of history. "Whether this long and tortuous development could have followed a different, more benign, course is not irrelevant." Bookchin, Murray, Post-Scarcity Anarchism, Op. Cit., p.10. 
section also reviews Bookchin's idea that the existence of a natural social consciousness in humanity occurs through the process of evolution.

Next, it demonstrates that Bookchin understands the natural social consciousness, or sensibility, of early "organic societies" to be the first stage of the dialectical development of human consciousness. Sensibility represents the original unity of an ethical consciousness with nature in human organic societies. Bookchin's approach is demonstrated to be an extension of Marx's attempt to ground Hegel's dialectic in nature — one in which the origins of the activity of consciousness are materially explained, and like Marx's understanding of labor, develop into antithetical components with the beginning of the application of abstract thought in society. In conclusion, it will be demonstrated that in his revision of Marx's model, Bookchin, like Marx, utilized the concept of a teleological end of history, and the implications of this conceptualization with regard to the claim for basing the dialectic in nature are noted.

Bookchin claims that society is natural - that there is no break between nature and humanity. In a reversal of Marx's attitude toward social production, Bookchin perceives nature not as passive with regard to the human creation of social reality, but as an active partner.

What, after all, is human society when we try to view it from an ecological perspective? A "curse?" An unmitigated "blessing?" A "device" for coping with material needs? Or, dare I say, a product of natural evolution as well as culture that not only meets a wide variety of human needs, but, potentially at least, can play a major role in fostering the evolution of life on the planet? ${ }^{73}$

More succinctly,

7 Ibid., p. 17. 
When we begin to consider socialization from an in-depth viewpoint, what strikes us is that society itself in its most primal form stems very much from nature. Every social evolution, in fact, is virtually an extension of natural evolution into a distinctly human realm. ${ }^{74}$

Contrast Bookchin's position with Marx's claims about the human-nature relationship. Marx clearly thought that humanity was responsible for its own development, as well as that of nature — in the sense that nature becomes more than physically unified with humanity because of human efforts to express itself through the manipulation of nature, thus giving nature 'intrinsic' value. For Marx, consciousness is only part of 'humanized nature' because of humanity's labor. Humanity is the focal point for Marx's philosophy, and so Marx's analysis of nature does not proceed beyond nature's relationship to humanity. For Bookchin, on the other hand, humanity neither creates its social self nor creates a 'humanized nature' strictly through its own efforts. Both stage one communities (and ethical sensibility) and stage two societies (and abstract consciousness) are products of the evolution of consciousness in nature into the particular form of human consciousness.

To support this claim, Bookchin relies upon anthropological studies of pre-literate, pre-hierarchical communities, which show that the "early social sensibilities" were internally related to nature. ${ }^{75}$ Notions of equality, kinship and usufruct (the individually free choice to use community resources) demonstrated that primitive social communities, like natural systems and animal communities, displayed an ethic and social structure that mirrors nature itself. Prior to the rise of artificial hierarchies and abstract rules, human

${ }_{75}^{74}$ Ibid., p. 25.

75 Bookchin, Murray, The Ecology of Freedom, Op. Cit., p. 44. 
social ties and values, like bonds and ritual behaviors in animal communities, were based on blood and birth. For example, members of early human societies, like the rest of nature, exercised their right to take from the rest of nature what they needed for immediate use or seasonal survival.

In a description of Hopi ceremonial dances, Bookchin draws the conclusion that early communities' displays of unity with the rest of nature reveal the fact that human beings, and their entire culture, physically emerge from a continuous natural evolution. Human social activity has a genetic or "blood" link to the animal community.

Hence, the very notion of nature is always social at this point in human development - in an ontological sense that the protoplasm of humankind retains an abiding continuity with the protoplasm of nature.... The dancers who imitate animals in their gestures or birds in their calls are engaged in more than mere mimesis; they form a communal and choral unity with nature, a unity that edges into the intimate intercourse of sexuality, birth and the interchange of blood. ${ }^{76}$

Here, Bookchin indicates that the "protoplasm of nature" forms an ontological basis for human reality. The physical unity with nature, through which the dialectic of development emerges, is expressed in our very being. Through human intercourse and sexual reproduction, humanity's physical heritage, like the physical heritage of the animal kingdom, emerges from the same genetic and evolutionary processes in nature.

However, the physical unity of these early organic communities with nature also reveals that the physical link between society and nature is associated with the socialization process of the young, a process which is also demonstrated throughout the animal world. In this way, Bookchin extends Marx's understanding of nature as the

76 Ibid., 48 . 
foundation for physical human reality by regarding nature at stage one (rather than production at stage two) as the foundation for human self-conscious, communal/social reality. Furthermore, by replacing the activity of human production with the activities of human "sensibility" and abstract consciousness, Bookchin simultaneously shifts the focus of social value from an economic understanding based on productive labor to an ethical understanding based on a natural socialization process. At the same time, Bookchin splits the conscious and ethical/value-laden activities of Marx's stage two of the dialectic, into aspects of two different stages of the dialectical development of consciousness in nature. Thus, for Bookchin's first stage of the dialectic, in contrast to that of Marx, 1) human communities exist as social realities; and 2) human consciousness exists as a natural reality.

For Bookchin, nature, more than mere physical being, has a conscious existence that, in an "abiding continuity," grades into human consciousness. Based on arguments from the early twentieth century biologist Robert Briffault ${ }^{77}$, Bookchin argues that in animals there is a kind of socialization that yields a consciousness, or intelligence, which is very similar to that of the human members of early societies.

'Throughout the class of mammals, there is a continuous increase in the duration of that association [mother and offspring], which is the consequence of the prolongation of the period of infantile dependence,' a prolongation which Briffault correlates with increases in the period of fetal gestation and advances in intelligence. ... it is a decisive presence, not only in the origins of

77 Murray Bookchin references Briffault's article, "The Evolution of the Human Species" in The Making of Man, V. F. Calverton, ed. (New York: Modern Library, 1931), pp. 765-766. See Bookchin, Murray, "Society and Ecology," Remaking Society, Op. Cit., pp. $26-27$. 
society over ages of animal evolution, but in the daily recreation of society in our everyday lives. ${ }^{78}$

Thus human socialization, including intelligence and the ethics of caring for members of the community and society, is grounded in the emotionally rich experiences of infant nurturing. In turn, fetal gestation and infant nurturing are social, conscious and ethical traits which exist throughout the mammalian class, emerging from nature and, more specifically, from female biology. ${ }^{79}$

According to Bookchin, the role of nature as the biological source for all aspects of human development and culture operates independently of the self-conscious, intentional activity of human beings. This is a reversal of Marx's position on human-nature relations, in which human society imprints itself on nature, and not vice versa. Most importantly, while Marx regards contemplation about the origins of consciousness as speculative, Bookchin claims to have understood the material/natural origins of human consciousness.

In the sense of operating independently from human consciousness, the developmental consciousness of nature, or "reason" (in the sense of encompassing both abstract and sensible aspects of consciousness), is a process governed by an abstract (historical-dialectical) concept. However, "reason," as the advanced development of

\footnotetext{
78 Ibid., pp. 27.

79 Thus, the overcoming of sexism plays a critical role in the overcoming of all 'isms' in hierarchical society, as women are naturally in closer touch with the "repressed intuition" of the victims of capitalist and communist societies. "Hence the revolutionary core of the women's liberation movement, which has brought the very syntax and musculature of domination into public view. [sic.] In so doing, the movement has brought everyday life itself, not just abstractions like 'Society,' 'Class,' and 'Proletariat,' into question." Bookchin, Murray, Post-Scarcity Anarchism, Op. Cit., p. 18.
} 
sensibility and analytical thinking in Bookchin's stage two of the dialectic, occurs only in human beings; likewise, human beings possess the ability to reason (ethically and analytically) through their physical link to nature.

Reason, as I have emphasized, has its own natural and social history that provides a better means of resolving its paradoxes than does a strictly intellectual strategy.... The formation of the human mind is inseparable from the socialization of human nature at birth and its early period of development. ${ }^{" 80}$

Thus, Bookchin views "reason" as non-abstract on the basis of both human socialization and the physical bond with nature through reproduction. Furthermore, "reason" is understood as part of nature, and bears the same physical (naturalist) relationship to human beings that Marx described for the inorganic aspect of nature. Humanity is part of reason and inorganic nature for Bookchin, and likewise, reason and inorganic nature are part of humanity.

Bookchin understands the third stage of the dialectic, or the resolution (or higher unity) of the historical dialectic of reason, as the goal of Western philosophy. The aim of social human consciousness is the unity of an ethical unity with nature and the analytical control of (or ability to manage) nature.

The melding of an organic, process-oriented outlook with an analytical one has been the traditional goal of classical western philosophy from the pre-Socratics to Hegel. Such a philosophy has always been more than an outlook or method for dealing with reality. It has also been what philosophers call an ontology - a description of reality conceived not as mere matter, but as active, self-organizing substance with a striving toward consciousness. ${ }^{81}$

\footnotetext{
80 Bookchin, Murray, The Ecologv of Freedom, Op. Cit., p. 304.

8) Jbid., p. 14.
} 
Here, Bookchin clearly identifies himself with a classic Western philosophic idealism. The goal, an enlightened returm to an original unity with nature, is one that Marx also shared. Bookchin's ontological orientation, however, unlike Marx's, cannot be said to be "humanist." Humanity, for Bookchin, becomes an expression of what material nature is striving toward. In a Hegelian-like twist, Bookchin contends that consciousness, the teleological end of nature, is self-creating and humanity is its highest expression. Humans are at the apex of the goal of self-consciousness toward which nature tends: "we are the very 'knowingness' of nature, the embodiment of nature's evolution into intellect, mind and self-reflexivity." ${ }^{92}$

So, the 'striving toward consciousness,' or the natural tendency of matter toward self-consciousness is, for Bookchin, a general description of nature, within which human beings are situated and are understood as the end result, the culmination, of the history of the consciousness of nature.

Conclusion: In conclusion, Bookchin makes an argument for the naturalness of consciousness (as an ethical sensibility and as abstract reason) and in this way extends Marx's idea of the physical unity between humanity and nature into the area of reasoning capacity and consciousness. It has been demonstrated that Bookchin reworks a historical dialectic in a manner that, like Marx, relies on nature, rather than an ideal or religious principle, as the source of conflict in society. Furthermore, he defends the idea that there is an intuitive aspect to ethics, and that the there is a parallel between what one can speculate to be the experience of human members of 'early organic societies' and the

$82 \quad$ Ibid., p. 38. 
behavioral aspects that human kind shares with the animal kingdom. Bookchin's turn to nature as a source for ethics does expand the discussion of value, understood within Marx's historical-material dialectic, namely as an economic concept.

Bookchin's approach is not as overtly "humanist" as is Marx's approach, in which humans are the only active parties in social development. Bookchin, on the other hand, regards the main dialectic to be a natural one, which plays itself out in nature and humanity. Marx, by contrast, regards the main dialectic to be a human one which plays itself out in nature and humanity. This difference in emphasis is also characteristic of Warren and Naess, who, like Bookchin, are concerned with the ecological threat to nature as a result of advanced socio-economic development - a concern which was not shared by Marx, who regarded such development as a necessary stage in the progress to harmony, a progression which Bookchin argues has not occurred.

Bookchin remains closely tied to Marxism, in that the tum toward nature as the ground for philosophy results in the development of an analysis which relies heavily on anthropological, historical, social and scientific detail to support its claims. However, both philosophers claim that there is only one correct interpretation of history. The belief in the dialectic of history, as the only correct theoretical viewpoint, does not accommodate the notion of "diversity," which is a significant part of the ecological outlook. Warren and Naess, like Bookchin, turn to nature as a base for philosophy and for an ethical approach to nature; however, unlike Marx and Bookchin, their philosophies attempt to allow for a diversity of theoretical viewpoints. 


\section{CHAPTER 3: WARREN: A PLURALIST ECOFEMINISM}

Karen Warren brings an environmental perspective to feminist philosophy (and a feminist perspective to environmental philosophy). The main purpose of her writings is to establish a theoretically adequate base for ecofeminism ${ }^{83}$. Central to Warren's ecofeminism is the relation between human and non-human nature, as well the transformation of feminism so that feminism is reconceptualized to mean "a movement to end all systems of oppression," ${ }^{34}$ including the human domination of non-human nature. This chapter focuses on 1) the centrality of pluralism to Warren's definition of ecofeminism; and 2) Warren's critique of other feminist theories with regard to their defensibility for supporting Warren's view of nature. In both areas of focus, the relationship of Warren's positions to Marx's "humanist/naturalist" approach is demonstrated. The purpose of this chapter is to show that Warren's assertions and claims in support of ecofeminism have direct philosophic roots in Marxist theory, and further to establish that Warren extends Marx's humanist/naturalist approach to philosophy by applying his critique of idealism and materialism to theories which exclude non-intellectual (i.e. ethical and emotional) aspects of human experience and do not allow for experiential diversity.

This chapter begins with a review of several of Warren's definitions and minimal conditions $^{85}$ that outline the boundary between what is and what is not ecofeminism, all

83 Ecofeminism is a term for ecological feminism, first introduced by Francoise de'Eaubonne. See Warren, Karen J., "The Power and the Promise of Ecological Feminism," Environmental Ethics, Vol. 12 (Summer 1990), p. 125-126.

84 Warren, Karen J., "Feminism and Ecology: Making Connections," Environmental Ethics, Vol. 9, No. 1, 1981, p. 18.

${ }^{85}$ Ibid., pp. 18-20. See also "The Power \& Promise of Ecological Feminism," Op. Cit., 
of which center on women-nature connections from the perspective of a transformative, pluralist feminism. It will be demonstrated that the assumptions underlying ecofeminism's pluralism owe a debt to Marx, especially to Marx's humanist orientation. Warren's focus is on experience of being human, especially with being female, with the resultant emphasis on the particular and human experience as the foundation for abstractions and generalizations.

This chapter also reviews Warren's critical examination of the liberal, Marxist, radical and socialist feminist perspectives on human/nature relations, concluding with a brief summary of a new set of "transformative" feminist minimum conditions that reflect ecofeminist criticisms of the four other versions of feminism. ${ }^{86}$ Warten presents very little information on her view of nature, but rather critiques other views on nature in order to define the boundaries of ecofeminist conceptions of nature. Despite her ecofeminist reliance on historical-materialism ${ }^{87}$ and on Marx's critique of traditional Western philosophy, Warren arrives at a position which accepts pluralism (within limits), thus deviating from Marx's (and Bookchin's) practice of arriving at one grand, theoretical synthesis to explain the human experience of reality and human-nature relations.

pp. 139-143 and "Toward an Ecofeminist Peace Politics," Ecological Feminism, edited by Karen J. Warren (Routledge: New York, 1994) pp. 187-189.

${ }_{86}$ " $[W]$ hat is needed is a new 'transformative' feminism, one which moves us beyond the current debate over the four leading versions of feminism and make an eco-feminist perspective central to feminist theory and practice." Ibid., p.5.

${ }_{87}$ Warren indicates support of dialectical materialism in two ways. One is through two of the four "minimal boundary conditions" of ecofeminism. A second is through her assumption of progress in history and the need for a universal transformation of a basic conflict in society between the victims of sexist-naturist oppression and the oppressors. This aspect of her philosophy is not discussed in this chapter. 
1. Definitions of Ecofeminism - From its inception, Warren's definition of the term 'eco-feminism' has allowed for a variety of theoretical positions stressing the importance of women-nature connections to be grouped under the same heading. Warren's theoretical approach is very similar to Marx's. Marx attempts to explore the complexities of, and to base his theories strictly on, particular facts and concrete human experience. Marx recognizes that theory is a particular expression of the real connections experienced by different individuals (or groups) in different social circumstances. Marx's theory is restricted to an analysis of the experience of capitalists and proletarians, while Warren's eco-feminism incorporates the theoretical exploration of real connections experienced by many different individuals and groups. Warren's view, however, does not attempt to unite these diverse theoretical perspectives into one all-encompassing theoretical framework.

In a 1987 article entitled "Feminism and Ecology: Making Connections," Warren identifies ecofeminists simply as feminists who agree that there are "important connections between the oppression of women and the oppression of nature" [referring to "the domination or subordination of nonhuman nature by humans"]. ${ }^{88}$ What distinguishes ecofeminists from other feminists involved in the ecology debate is their conviction that an understanding of the connections between the oppression of women and the oppression of nature is " potentially liberating." "'89 These characteristics specifically delineate ecofeminism and form the first two of four basic claims identified by Warren as serving as "a minimum condition account of eco-feminism:"

\footnotetext{
88 Warren, Karen J., "Feminism and Ecology: Making Connections," Op. Cit., p. 4. 89 Ibid., p. 4.
} 
[E]co-feminism is a position based on the following claims: (i) there are important connections between the oppression of women and the oppression of nature; (ii) understanding the nature of these connections is necessary to any adequate understanding of the oppression of women and the oppression of nature....

For ecofeminists, the study of women-nature connections is desirable for a variety of reasons, such as its potential to transform world views and to inspire the creation of alternative value systems. In further developing this working definition, Warren provides no specific theory of the connections between the oppression of women and that of nature; she does this for a variety of reasons, including allowing ecofeminism to embrace positions which are based on competing feminist theories. The extent of differences among them encompasses a full range of philosophic reflections.

The varieties of ecofeminism reflect not only differences in the analysis of the woman/nature connection, but also differences on such fundamental issues as the nature of and solutions to women's oppression, the theory of human nature, and the conceptions of freedom, equality, and epistemology.... ${ }^{91}$

The remaining two boundary conditions formalize Warren's conviction that women-nature connections are of central importance to the overcoming of all oppressions, and therefore are necessary for any movement opposing oppression, especially the feminist and ecology movements, to achieve their respective goals. Claims (iii) and (iv) specify the mutual requirement of feminism to be ecological and ecology to be feminist: "(iii) feminist theory and practice must include an ecological perspective; and (iv) solutions to ecological problems must include a feminist perspective."92 Through her

90 Ibid., p. 4-5. Claims (iii) and (iv) concern the mutual requirement of feminism to be ecological and ecology to be feminist.

91 Ibid., p. 4.

92 Ibid., p. 4-5. 
refinement of the definition of ecofeminism and her review of the inadequacies of non-ecofeminist feminism, Warren articulates a second set of boundary conditions that centralizes the importance of women-nature connections and can be applied to all feminist perspectives. Both her definition of ecofeminism and her second set of boundary conditions (for transformative feminism) emphasize diversity and social context (which in ecofeminist boundary condition (iv) is limited to the context concerning "ecological problems").

A distinctive feature of Warren's ecophilosophic work has been her consistent effort to define a conceptual and minimal framework for ecofeminism, one which will serve as a basis for the continued development of a theoretical model that includes the voices of diverse women. These voices differ in their mode of expression; that is, these viewpoints are not only analytical, but incorporate other aspects of conscious experience. They include artistic, conceptual, personal, and spiritual viewpoints. Also, differences in local cultures across the globe have produced different histories of women over time. Warren's concern for diversity, which qualifies her initial definition of the term 'ecofeminism,' becomes a component of her formal definition of ecofeminism in the 1990 article, "The Power \& Promise of Ecological Feminism." There, Warren defines 'ecofeminism' as "the position that there are important connections - historical, experiential, symbolic, theoretical - between the domination of women and the domination of nature." 93 This change reflects the centrality of her tolerance for a

93 Warren, Karen J., "Power and Promise of Ecological Feminism," Op. Cit., p. 125. See also Warren, Karen J., "Introduction," Ecological Feminism, Op. Cit., p. 1. for expanded list, including empirical, religious, literary, political, epistemological, etc. 
multiplicity of views concerning woman-nature connections, so much so that multiplicity is built into her definition of 'ecofeminism.'

By 1994, Warren expounds the definition of 'ecofeminism' in the following way.

[A]n umbrella term which captures a variety of multicultural perspectives on the nature of the connections within social systems of domination between those humans in subdominant or subordinate positions, particularly women, and the domination of nonhuman nature. ${ }^{94}$

The use of terms such as 'umbrella," 'variety' and 'multicultural' captures the diversity aspect which qualifies the above definitions. This most recent expanded definition of ecofeminism continues to recognize the importance of human/nature connections, but it also contains a direct reference to the social context in which human connections occur, beyond the limits of solving ecological problems. Human connections to nature, as the above quote demonstrates, parallel the social relations between groups of humans. As is the case with Marx, human to non-human nature relations match the level of human social development. Warren, however, does not base her judgment on property relations, but rather on relations of domination.

The multi-cultural, social context approach to ecofeminism reflects both a Marxist and feminist heritage. First, the reference to social settings as 'social systems of dominance,' coupled with the exclusive focus on the perspectives of dominated humans, is indicative of a strong affiliation with historical materialism and/or social ecology $y^{95}$

\footnotetext{
94 Karen J. Warren, "Introduction," Ecological Feminism, Op. Cit., p. 1.

95 Warren states that ecofeminism "is a social ecology. It recognizes the twin dominations of women and nature as social problems rooted both in the very concrete, historical, socioeconomic circumstances and in oppressive patriarchal conceptual frameworks which maintain and sanction these circumstances," "The Power and the Promise of Ecological Feminism," Op. Cit., p. 143.
} 
which as shown in Chapter 2 is a development based on a revision of the Marxist model. Second, the multi-cultural/diversity aspect of Warren's definition of ecofeminism, as well as the centrality of women's oppression "within social systems of domination," is based on an explicitly feminist perspective.

2. Social context of domination - Warren's incorporation of socialist feminism into ecofeminism expands the pluralism of ecofeminist perspectives. Ecofeminism not only encompasses the women's-voice perspective, but includes the perspectives of men who share subordinate status in the Western patriarchal cultural hierarchy via their class, race, sexual preference, ethnic, or other subdominant group affiliation.

By this inclusion of the oppressed-male perspective, ecofeminism claims that the 'domination of non-human nature' is socially linked to the systematic domination of any oppressed person and to all types of oppression (human and non-human). This claim parallels Marx's claim that society's transition to communism will resolve all conflicts "between man and nature and between man and man" because the process of the objectification of humanity in nature (property, under capitalism) is a social process impacting all human/nature relations. ${ }^{96}$ This aspect of inclusiveness, therefore, is a generalization of ecofeminism in terms of its universal applicability. So, while diversity allows for expanding the theoretical basis of ecofeminism to all groups, the particular perspective of a diverse ecofeminism is extended to all oppressed groups. The exclusion of the viewpoint of the oppressors represents the boundary of, or limits to, Warren's theoretical diversity. In this respect, ecofeminism, like Marxism, generalizes its

96 See Chapter One, page 20 and 26-27. 
conceptual framework (which accommodates a diversity of theories) across one side of the social conflict.

Further, Warren highlights the individual and unique perspective of 'those humans in subdominant or subordinate positions,' so that their particular views are included among the various possible conceptual viewpoints on the connections between human and non-human oppression. The approach to understanding the individual from the perspective of his/her social context, which Marx asserts is the only method of understanding humanity, is also taken by Warren. While Marx approaches individual experience as particular social facts which emerge in a particular context of social production, and are thus fit into a unified theoretical context, Warren shares the feminist perspective that celebrates differences in circumstances and viewpoints (that are not economic or class based). Feminism and ecofeminism posit these different views and experiences in a framework which delineates a variety of theoretical perspectives and even attempts to incorporate the unique and non-generalizable voice. ${ }^{97}$ Warren expresses this view in a discussion of theory building, focusing on ethical concerns. "When a multiplicity of cross-cultural voices are (sic.) centralized, narrative is able to give expression to a range of attitudes, values, beliefs, and behaviors which may be overlooked or silenced by imposed ethical meaning and theory." 98

\footnotetext{
97 "From a feminist point of view, impartiality ... involves being sure that the felt experience of women, however diverse those experiences may be, are part of theory building." Warren, Karen J., "Critical Thinking and Feminism," Informal Logic, X.1, Winter 1988, p. 39.

${ }_{98}$ Warren, Karen J., "The Power \& The Promise of Ecological Feminism," Op. Cit., p. 136.
} 
3. Feminist context of oppression - From a feminist perspective, multicultural/diversity and the centrality of women's oppression "within social systems of domination" are explicitly linked themes. However, Warren's particular feminist perspective is based on 1) socialist feminist theory, with its explicit debt to Marx and Marxism; and 2) the critique of the patriarchal conceptual framework, with its explicit foundation "in familiar ecological principles," ${ }^{, 99}$ and implicit parallels to Marxist theory. Before continuing to compare and contrast aspects of the environmental philosophy of Karen Warren with the philosophy of Karl Marx, it is important to note that Warren's position draws heavily on feminist conceptions which are not present in Marx. Marx did not engage in gender-based analysis to overcome male-bias, nor did he privilege women as key to the humanist transformation of nature or to the synthesis of natural intuition. He merely noted that the closest natural human relation is the male-female relation; and that therefore the social institutions governing the relation of women to men bear a direct relation to (or are indicative of) the general level of society's objective relation to both human and non-nature. However, many of the criticisms which Marx leveled against the capitalist system, idealism and abstract materialism are similar to Warren's criticisms of patriarchy and of the theoretical foundations of the four leading schools of feminism.

4. Four Schools of Feminist Thought on Nature - In "Feminism and Ecology: Making Connections," Warren posits ecofeminism within the "feminist debate over

99 Warrens claims that the "critique of patriarchal conceptual frameworks [a critique which is "central" to the ecofeminist project] is grounded in familiar ecological principles: everything is interconnected with everything else; ... healthy, balanced ecosystems must maintain diversity; there is unity in diversity." (emphasis mine). "Feminism and Ecology: Making Connections," Op. Cit., p. 7. 
ecology," a debate reflective of four schools of feminist thought: liberal, traditional Marxist, radical and socialist feminism. Warren claims that "just as there is not one version of feminism, there is not one version of ecofeminism." 100 This claim, however, is not meant to indicate an ecofeminist acceptance of the ecological implications of these different versions of feminism. As will be indicated by the nature of Warren's ecofeminist criticisms of the main branches of feminist thought, Warcen's arguments supporting multi-culturalism/diversity and the social context of women's experience display a debt to Marx's naturalist approach. Marx prioritizes the particular, historical-individual experience as the foundation of theory, rejects idealism as the foundation of theory, and claims that the understanding of human experience and the development of theory cannot be separated from the social context within which they occur.

Liberal feminism. This section demonstrates that Warren's critique of liberalism, which has a foundation of "extreme individualism"101 (based on an abstract, ahistorical conception of human beings) and corresponding individualistic and rational-based outlook, relies upon Marx's critique of abstract materialism.

The ecological implications of liberal individualism, with its emphasis on reason as the essential activity of humanity, conflict with ecofeminism's emphasis on "the independent value of the integrity, diversity, and stability of ecosystems" and the "equal value to all parts of the human-nature system." ${ }^{\text {"102 }}$ Ecofeminism, given the ecological

\footnotetext{
100 Ibid., p. 4.

101 Ibid., p. 10.

102 Ibid., p. 10. For underlying premise of the claim for "equal value..." (i.e., the priority given to relations, rather than to relators as moral agents. within the human-nature
} 
implications to which Warren refers, focuses on values. Unlike Marx's neglect of ethical values, ecofeminism makes ethical opposition to the moral value system associated with the patriarchal conceptual framework ${ }^{103}$ an important aspect of its theory. Warren argues that liberal feminist ethics, i.e. individual-rights based ethics, is an inadequate base for ecofeminist ethics because it draws on "hierarchical rights- and rules-based ethical models." These models are based only on the perspective of the dominant members of society, and thus conceal the moral viewpoint of subordinate groups, i.e. women whose social circumstances differ greatly from those of the dominant male group. The "extreme," or abstract, individualistic ethics of liberalism does not consider the social context of the individual, which is a main component of Warren's definition of ecofeminism. The individual is understood as a rational being, whose thought is eternally valid regardless of the socio-material conditions (class, sex/sexual orientation, ethnicity, etc.) within which individuals exist. Furthermore, what is rational is 1) defined by members at the top of a dominating, hierarchical social structure; and, 2) obscured under the guise of universalism, as it appears in the particular ruling class, male-based bias in liberal ethics. Warren draws on feminist scholarship for examples of why ecofeminists should be "suspicious of approaches to feminism, ethics, or ecological concerns based on a patriarchal conceptual framework." ${ }^{2104}$ Warren utilizes arguments made by philosopher Kathryn Pyne Addelson to link the ecofeminist critique of traditional ethics to the

system), see Warren, Karen J., "The Power and the Promise," Op. Cit., pp. 135-137. ${ }_{103}$ A study of ecofeminist ethics and its critique of the hierarchical value system of patriarchy is not part of this paper, as the subject would require a separate chapter. 104 Ibid., p. 11. 
ecofeminist critique of liberal feminism. Citing Addelson, Warren explains that the bias in the dominant liberal world view

'allows moral problems to be defined from the top of various hierarchies of authority in such a way that the existence of the authority is concealed, and so the existence of alternative definitions that might challenge that authority and radically change our social organization is also concealed. ${ }^{105}$

Although Warren explicitly rejects liberal feminism on the grounds of its acceptance of a liberal ethics stemming from the 'patriarchal conceptual framework,' her reasoning reveals a rejection of arguments based on the idea of an abstract and socially isolated individual. This correlates to Marx's rejection of the individualist viewpoint in liberal economics. Recall that Marx rejects arguments that are based on "arbitrary" or dogmatic abstractions (i.e., abstractions which are not based on understanding the "real" individual as living in a particular, social context). Furthermore, Marx regards liberal economic theory as concealing economic power relations and value, just as Warren regards liberal ethical theory as concealing patriarchal power relations and ethical bias. Marx understands that intrinsic value relations are hidden in commodities and in objective human relations (those relations which serve as the basis for the objective satisfaction of needs).

Traditional Marxist feminism. Warren's critique of Marxist feminism reveals that her interpretation of Marx incorporates the "early" Marx's broad-based conception of consciousness and emphasis on particular, real, living human beings (rather than class consciousness) as the basis for theory. Further, with regard to nature, Warren indicates

10s Kathryn Pyne Addelson, "Moral Revolution," in Women and Values, p. 306, cited by Warren, Ibid., p. 10. 
that although the development of nature and the social status of women have been linked in the past, they may not be linked in the future - a possibility which Marx did not admit, thus making Warren's identification of nature with social development historically contingent and not ontologically united.

In reviewing traditional Marxist feminism, Warren outlines the basic Marxist insight of the "social construction" of knowledge. ${ }^{106}$ She clearly indicates that the Manxist social conception of knowledge is part of ecofeminist epistemology. Unlike traditional Marxist feminists, ecofeminists expand Marxist epistemology to incorporate radical feminist epistemology, which includes "felt experiences" as a particular source of knowledge based on experiences of the individual in a variety of social contexts. This epistemological extension, which echoes Bookchin's conception of "ethical sensibility," conflicts with Marx's relegation of emotional awareness ("suffering") to stage one of the dialectic. Recall that for Marx, this natural emotional awareness is not a basis for knowledge. Transformative (ecological) feminist epistemology, by grounding knowledge in non-generalizable, personal experiences, "provide[s] a central theoretical place for the diversity of women's experiences, even if this means abandoning the project of attempting to formulate one over arching feminist theory or one women's voice."107

Warren summarizes the traditional Marxist feminist definition of human being: they understand human nature praxeologically; that is 1) as in the process of developing historically and socially; and 2) as active beings whose "conscious physical labor [is]

106 Tbid., p. 12.

107 Ibid., p. 18. 
directed at transforming the material world to meet human needs." ${ }^{108}$ Although Warren's stress on the importance of historical factors and social context for an ecofeminist transformation of the world is compatible with her summation of Marxist feminist ontology, she acknowledges that there are key differences with regard to the Marx-Engels materialistic view of nature. Warren does not take a position on whether or not traditional Marxism can develop a view of nature which does not over-emphasize the human objectification of nature and the role of nature in materially satisfying human needs. Yet, recall that Marx understood human/nature relations as eventually being transformed so that nature is self-consciously recognized as being part of humanity and as having value by virtue of being part of humanity. Warren, on the other hand, claims that central conceptions within ecofeminism are grounded in ecological principles, such as "all parts of an ecosystem have equal value," 109 thus raising the possibility that an ecosystem without connection to humanity has value. While Warren cites problematic ecological implications of this ontology, she holds open the possibility for a traditional Marxist feminist reinterpretation of human relations with nature.

Indeed, the most "significant" of the ecofeminist challenges to traditional Marxist feminism does not directly concern nature relations but is based on their "general failure to take seriously gender as a constitutive category of social reality. ${ }^{110}$ By ignoring gender,

\footnotetext{
108 Ibid., p. 12.

109 See footnote 100, p. 57 of this text.

110 Warren, Karen J., "Feminism and Ecology: Making Connections, Op. Cit., p. 13. See part (iii), Radical Feminism, of this chapter section for discussion of gender as an important category of human experience.
} 
traditional Marxist feminists are not placing significance on the particularity of social reality (i.e. gender as a personal aspect of human experience.)

Warren's two other criticisms of traditional Marxist feminism, however, do emphasize the conflict between humans and nature. First, Warren suggests that traditional Marxist feminists need to adjust their "claims about nature with a political vision that does not pit men and women, as one class, over and against nature" and does not maintain the "patriarchal conceptual framework" which could continue to uphold the exploitation of nature "even if women get elevated to equal status with men (but against nature.)"s11 This suggestion implies that the conceptual connections between the domination of women and of nature are separable, in that Warren admits of the future possibility that the domination of nature could continue, but sexism be abolished. Second, Warren suggests that traditional Marxist feminists need to go beyond a negative conception of environmental problems as a function of capitalist means and forces of production, to develop a positive conception of human/nature relations in which a "liberating or appropriate technology and science, based on ecological principles, could help protect and preserve, rather than exploit, nature."112

Radical feminism. Warren adopts two aspects of radical feminism in clarifying ecofeminism, both of which extend Marx's theoretical foundation. First, radical feminist ontology emphasizes particular traits, including their laboring activity but most

\footnotetext{
111 Ibid., p. 13.

${ }^{112}$ Warren, Karen J., "Feminism and Ecology: Making Connections," Op. Cit., p. 13. Warren's criticisms here is comparable to Murray Bookchin's critique of the environmental degradation in the soviet and socialist economies.
} 
importantly their gender, as an important aspect of the individual's material body and situates individuals within a patriarchy. In a parallel fashion, Marx's ontology emphasizes particular (or real-life) activity as an important aspect of the individual's material body and situates individuals within a social system of production. Second, it is an innovative feature of "radical feminist epistemology [to] self-consciously explore strategies (e.g., consciousness-raising processes) ${ }^{n 113}$ that challenge the bias toward reason as the supreme source of knowledge, a bias that persists in Marx's and Bookchin's conception of consciousness. ${ }^{114}$ By adopting alternative strategies, ecofeminism extends Marx's reason-based, epistemological demand for concrete living proof of knowledge to include the wisdom of emotions and felt experience as living sources of knowledge in concrete circumstances. ${ }^{135}$ In these two ways, Warren claims, radical feminism makes a contribution to ecofeminist theory by furthering the process of overcoming "distortions of patriarchal ideology." 116 Its positive contributions are incorporated into socialist and transformative eco-feminism, both of which "wed the insights of traditional Marxist feminism and radical feminism."117

\footnotetext{
113 Ibid., p. 14.

114 It should be noted that Bookchin does incorporate intuition as the basis for ethical sensibility, in his concept of the consciousness of nature. However, he places primary importance on analytical thinking as a "higher" type of consciousness, thus subjugating his foundation of a natural ethic to the rule of analytical reason, a rule which becomes benevolent with the synthesis of these two forms of 'reason.'

115 It should be noted that radical feminists are not the only philosophers who emphasize feelings and intuition. Blaise Pascal, Max Scheler and Ame Naess are examples of male philosophers in the minority tradition of Western philosophy who also reject this bias. ${ }_{116}$ Karen J. Warren, "Feminism and Ecology: Making Connections," Op. Cit., p. 14. 117 Ibid., p. 16.
} 
On the negative side, Warren rejects radical feminism's dualist approach to women-nature relations because of its 1) overall lack of attention to, or denial of, historical conditions; and 2) mystification of human-nature connections. These, of course, are the two faults which, respectively, are part of the philosophical premises of 19th century materialist and idealist philosophies, according to Marx in the German Ideology. Warren's criticisms of the foundation of radical feminist positions, understood in terms of the question "“Are women closer to nature than men?,"'18 reveals the similarity between Marx's critique of idealism and materialism and Warren's critique of radical feminism. On the one hand, radical 'nature' feminists affirm women's "close connections" to nature to encourage a "transform[ation of] our spiritual consciousness so as to be more in tune with nature." 119 On the other hand, other radical ferminists deny women's special relationship with nature.

Thus, radical feminist ecology "pays little attention to the historical and material features of women's oppression (including the relevance of race, class, ethnic, and national background)" and does not ground its analysis in "concrete and diverse social structures." 120 In addition, the radical feminist ecological question ("Are women closer to nature than men?') either 'mystifies women's experience to locate women closer to nature than men" or "underplays important aspects of the oppression of women to deny the connection of women with nature."121 The question, "Are women closer to nature than men?,' Warren argues, ignores a basic assumption of ecofeminism underlying its

$\begin{array}{ll}118 & \text { Ibid., p. } 14 . \\ 119 & \text { Ibid., p. } 14 . \\ 120 & \text { Ibid., p. } 15 . \\ 121 & \text { Ibid., p. } 15 .\end{array}$


anti-dualism: "the truth is that women, like men, are both connected to nature and separate from it, natural and cultural beings." 122 In affirming the claim that both men and women are connected simultaneously to nature and to culture, Warren implicitly acknowledges the basic ontological unity between human beings and nature that Marx and Bookchin recognize as essential to the definition of humanity.

Further, Warren expresses sympathy toward an "understandable" socialist feminist guardedness with regard to such dualist arguments concerning "women's spiritual or sex-gender-based connection with nature." ${ }^{.123}$ Her claim is that radical feminists ignore the facts of feminist scholarship, which have revealed the fallacy of 'nature-culture dualism.' Her argument can be seen as compatible with that of traditional Marxist feminism in that the "mystifying" of nature experiences is a consequence of not sufficiently grounding one's viewpoint on concrete facts, including historical facts. Warren's criticisms of radical feminist ecology are the same as her criticisms of philosophies of essence: Both are based on concepts which are ahistorical and mystifying. In "The Power \& Promise of Ecological Feminism," Warren asserts the ecofeminist "assum[ption] that there is no essence (in the sense of some transhistorical, universal, absolute abstraction)."124

Her critique of mystifying, ahistorical, philosophies of essence is compatible with Marx's two-part critique of mysticism in the German Ideology. It demonstrates acceptance of at least two main features of Marx's epistemological theory: 1) a demand that facts, analyses and abstractions be sufficiently grounded in concrete, socio-historical

\footnotetext{
122 Ibid., p. 15.

123 Ibid., p. 17.

124 Warren, Karen J., "The Power \& Promise of Ecological Feminism," Op. Cit., p. 138-139.
} 
conditions (inclusive of dominant ideologies) and, consequently, a rejection of facts, analyses and abstractions based on transhistorical, ahistorical or idealist assumptions; and 2) a suspicion that spiritual experiences, while in themselves legitimate, mystify the causal historical facts and conceptions which are at the base of given social problems, insofar as these experiences give rise to arguments based on 'essence.'

Socialist feminism. Of the four leading versions of feminism, Warren states that "it might seem that it [socialist feminism] would provide the most promising theoretical framework for eco-feminist concerns." ${ }^{25}$ It combines historical materialism with gender analysis and studies the connections between economic and sexist social systems of oppression, just as ecofeminism is concerned with the systematic social connections between the oppression of human and natural systems. Likewise, socialist feminism regards the economic and sexist systems as mutually and "dialectically" reinforcing and as requiring a joint overcoming of "capitalism" and "patriarchy" in order to secure the "liberation of women." "s26 This corresponds to (iii) and (iv) of Warren's four original minimal boundary conditions, in which ecofeminists regard the oppression of women and nature as mutually reinforcing and directly linked. The overcoming of sexism requires the overcoming of "naturism"127 (and vice versa). The only criticism Warren directs at socialist feminism is its lack of incorporation of "naturism" as a systematic oppression

\footnotetext{
125 Warren, Karen J., "Feminism and Ecology: Making Connections," Op. Cit., pp. 16-17.

126 Ibid., p. 16.

127 Naturism is defined by Warren as "the domination or oppression of nature," in Warren, Kareen J., "The Power \& Promise of Ecological Feminism," Op. Cit., p. 32.
} 
linked to all the other social oppressions, (i.e., classism, racism, sexism, imperialism, etc.).

After reviewing and critiquing the four major schools of feminist thought, Warten offers six new boundary conditions as "suggestions about how such a transformative feminism might be developed" in the future. Her debt to Marxism is clearly indicated by the fact that four of these conditions of a future transformative feminism are attributable to socialist feminist theory. They are 1) the understanding of "structural interconnections" between various forms of oppression, such that ecofeminism can become a "movement to end all forms of oppression; 2) the social and experiential concept of knowledge, such that ecofeminist politics "asserts the value and specificity of group difference in political theory and practice;" 3 ) the emphasis on the interplay of human and nonhuman connections concerning our ontological conceptions of human beings and our conceptual frameworks; and 4) technological research, technology and science applications need to be used in ways that are non-oppressive. ${ }^{128}$ The remaining two suggested boundary conditions for transformative feminism stem directly from the feminist critique of the patriarchal conceptual framework, ${ }^{129}$ and are not attributable to a link with the philosophy of Karl Marx.

Conclusion: Much of what is distinctly 'ecofeminist' in Warren's analysis is based on an extension or reinterpretation of Marx's understanding of human-nature relations:

128 Warren, Karen J., "Feminism and Ecology: Making Connections," Op. Cit., pp. 18-20.

129 The specific concerns raised in the remaining two 'suggestions' concern the ecofeminist critique of patriarchy as it relates to the 'logic of domination' and ethics, two areas of concern which, as Bookchin noted, were sorely lacking in Marxist-Leninist inspired philosophy. 
1) a focus on the priority of human beings in a specific context as the basis of theory that includes 'felt,' as well as 'reasoned' experiences; 2) acceptance of an all encompassing dialectic, but the pluralistic rejection of devising a grand theory, a rejection made on the basis of upholding respect for the variety of 'reasoned' perspectives legitimately developed by individuals; and 3) an expansion of Marx's idea that the level of social development in society (with respect to overcoming class domination) is directly linked to the relationship between human and non-human nature, adding the overcoming of sexism, racism and naturism as part of the dialectical transition of society.

Like Bookchin, Warren relies heavily on Marx's socio-historical analysis to comprehend human/nature relations. Furthermore, she incorporates the 'feeling' or personal aspects of human experience into the foundation of theory-building, so that an intuitive and experience-based ethic can be incorporated with "material conditions" to form a concrete basis for new understanding of human/nature relations. The priority Warren gives to 'feeling' and experience overcomes the analytical bias that is part of Bookchin's attempt to develop a natural, concrete basis for ethics (an area of study largely ignored by Marx). Naess, like Warren, pushes past Marx's relative silence and Bookchin's analytical bias to explore the uniquely personal aspects of human experience. Naess, unlike Marx,incorporates feeling, intuition and belief into his version of a modified empirical outlook on human-nature relations. 
CHAPTER 4: NAESS: VALUE AND HUMAN/NATURE RELATIONS

One of the primary issues in the ecological philosophy of Ame Naess is highlighting the place of values in human/nature relationships. His understanding of value is not Marxist; it does not rely on historical analysis, dialectical materialism or the labor theory of value. Further, the term 'value' is used in its modern sense, having a wider meaning for Naess than for Marx, i.e., encompassing ethical, religious, aesthetic and other types of value as well as economic value. Yet despite these major differences, Naess's overall approach to value theory echoes themes addressed in the early works of Marx, pivoting around the main idea that philosophy must ground itself concretely on the real relations between human beings and nature.

The purpose of this chapter is to demonstrate that Naess, like Marx, approaches philosophy from a modified empirical perspective. Both Naess and Marx modify strict empiricism by incorporating the contextual relations within which humans actually exist into the founding premises of philosophy. In the attempt to bring human experience into empirical debate, Marx focuses on the historical, social and economic context of human activity in and experience of the world, while Naess adds to these the immediate personal and natural context of the human experience in the world. In addition, it will be demonstrated that Naess develops a systematic method for understanding human experience, one that is based on the incorporation of ethical value into the concrete and dynamic real world of human experience. Further, Naess's claim that his concept of the ethical value of nature, like Marx's concept of the labor theory of value (of commodities), arises from concrete human interaction with (or experience of) nature and is used to critique 
contemporary, scientific or other empirical evaluations of the value of nature as grounded in an unrealistic (i.e., abstract) view of the human/nature relation.

Naess extends Marx's empirical approach to value beyond its narrow, economistic application. Naess also appeals to the phenomenological experience of nature to demonstrate empirically that the human/nature relationship gives rise to the human conception of value. Throughout this chapter, parallels to Marx's criticism of empirical methods, differences in Marx's and Naess' conceptions of nature, and the centrality of human/nature relations in value theory will be noted.

\section{Naess's modified empirical approach to assessing the value of nature - This} section reviews Marx's conception of the general role of value in social theories that are based on historical facts and compares Marx's viewpoint with Naess's conception of the general role of value in social policy debates that are based on scientific facts.

Both Marx and Naess are critical of the traditional empirical and scientific attitude, which understands nature as an entity that is isolated from human experience (experience, here, is understood to include the human judgments based on the concept of intrinsic value.) According to Marx and Naess, nature can only be understood in terms of human/nature relations, dynamic relations which encompass human assessments of the value of nature. Further, the human recognition of the value of nature does not conflict with an empirical, scientific approach to the study of society. Rather, it prompts the formulation of social policy and social theory which, while not based on an abstract understanding of human experience, nonetheless is more realistic and relevant to social analysis than are purely objective, empirical-scientific approaches. 
To illustrate how Naess justifies his claim that discussion of the ethical value of nature can be empirically conducted, consider the following example. Naess claims that nearly everyone, upon investigation of their own value priorities, would arrive at the conclusion that nature (non-human life forms) has inherent value, independent of human needs. In "Intrinsic Value: Will the Defenders of Nature Please Rise,"130 Naess refers to his survey of policy experts in Norway (which had a statistically valid sample size of 110) for empirical evidence supporting this claim: in reaction to the first of eight points in the "deep ecology platform," "the great majority indicated their agreement" to these two statements: "The flourishing of human and non-human life on Earth has inherent value. The value of non-human life forms is independent of the usefulness of the nonhuman world for human purposes." ${ }^{131}$ According to Naess, the judgments - that a) non-human life forms have intrinsic value ${ }^{132}$ and b) non-human life forms are not merely means to a human end - are facts, based on the empirical evidence grounded in the real existence of this judgment as a human opinion. Naess further cites the fact that there exists no "opposite articulated philosophy" which claims that nature has no intrinsic value. He takes this to support his claim that the statement "non-human life forms have intrinsic value" is systematically, philosophically defensible. ${ }^{133}$

130 Published in Wisdom in the Open Air, Edited by Reed, Peter and Rothenberg, David, (Minneapolis: University of Minnesota Press, 1993), pp.70-82.

131 Ibid., p. 76.

132 Naess uses the terms 'inherent value' and 'intrinsic value' synonymously.

133 Ibid., p. 77. Similar arguments are made in Ecology, Community and Lifestyle, Op. Cit., see pp. 29, 66-67, 87-88 and 176-177. For an argument against Naess's position that deep questioning leads to some form of affirmation of the inherent value of non-human nature, see Warwick Fox, Toward a Transpersonal Ecology, (Boston: Shambhala; New York), 1990, Chapter 5. For arguments defending Naess's claim see Harold Glasser, "On Warwick Fox's Assessment of Deep Ecology", Environmental 
Naess's empirical approach to the study of value, like Marx's approach, demonstrates a quantitative analysis of value. In Marx's study of the commodity, the quintessential physical manifestation of capitalism, he emphasizes economic value and asserts that the value of each commodity is created by labor through the interaction of human and non-human nature. The physical embodiment of human value in the commodity allows for the empirical study of value: the value of $x$ is the worth of $x$, measured by price and determined by labor (broadly conceived to include the social context of the relevant, specific intellectual and physical activities). For Marx, only labor creates value in (or gives worth to) nature and things created from natural objects. Therefore, according to Marx, value is an economically measurable (and also a historically factual) portion of the human "life active process," a process which forms the "naturalist" base for arguments involving historical facts.

Although Naess's approach is an attempt to analyze judgments concerning the intrinsic value of nature, and not a measurement of economic value, both Marx and Naess claim that their approach is a better description of reality than those provided by the social scientists of their respective times. Naess, like Marx, argues that the presence of human activity (specifically the activity of formulating ethical judgments) is crucial to socio-economic and socio-political analysis.

Recall that Marx's method of historical analysis is empiricist, modified by the assertion that the first premise of empirical arguments is actual human life in a particular natural and socio-historical context. According to Marx, the "active life process" of

Ethics, Vol. 19, Spring 1997, pp. 75-82. 
human interaction with nature must serve as the premise for all empirical social studies - otherwise empiricism is not grounded in reality. In this way Marx demands that the complexity and fullness of human being (including humanity's value creating potential) be recognized as the basis of a scientific, dialectical-materialist approach (as opposed to the both "abstract" idealist or pure empiricist approaches) to philosophy. Thus, in his dialogue with historians and political economists (the social policy experts of his day), Marx asserts that empirical arguments would be less "abstract" and hence more realistic if they incorporated descriptions of the "active life-process" of humanity, within a socio-natural context, into their theory. Indirectly, then, Marx includes labor value (and thus the intrinsic value of nature as he defines it) in the "real premises" of historical analysis.

Naess makes a similar claim in his dialogue with the scientific advisors to political policy makers; although, his appeal for the inclusion of statements concerning the intrinsic value of nature into the premises of empirical arguments is a direct one. Naess, like Marx, is concerned about introducing an active human life process into social science in a non-"idealist" or non-"abstract" way. Also like Marx, he states that the method (or "approach") of the empirical science of ecology would be improved if it incorporated human activity (in the form of ethical evaluation) into the measurement and assessment of facts. ${ }^{134}$

\footnotetext{
134 Naess is not rejecting Marx's demand that social analysis include economic class and power relations. Rather, Naess is claiming that ethical values underlie assumptions about the 'goodness' of various social policies (such as a policy in favor of an equitable distribution of wealth). See Naess, Ecology, Community and Lifestyle, p. 105.
} 
Chemistry, physics, and the science of ecology acknowledge only change, not valued change. But you and I would presumably agree that a change in the bio-conditions of a river or ocean which excluded most forms of life would constitute a deterioration of value. ... The inability of science to denounce such processes as the washing away of the soil of rain-forests suggests that we need another approach which involves the inescapable role of announcing values, not only 'facts'. ${ }^{135}$

An analysis of the context of the above quote demonstrates that the "values" Naess wants scientists to announce are ethical values, not economic ones. For Naess, the value of $x$ is not merely a question of the worth of $x$, but rather a question of the good of $x$. Naess appeals to common sense to support his claim: "you and I presumably agree that a change in the bio-conditions of a river... constitute[s] a deterioration of value." By 'deterioration,' most people mean a "change for the worse, a decrease in value." 136 Furthermore, he claims that the judgment that this change in value is 'bad' presupposes an ethics. "An ethical theory is presupposed, a system which allows one to judge a change as negative."137 Therefore, by "denouncing" or praising a change in the "bio-condition of a river," scientists would be adding their ethical evaluation of the "facts" instead of merely presenting "factual" information. Just as Marx appeals to social thinkers to include the dynamic human activity of labor in the analysis of otherwise "dead facts" (Marx's phrase), Naess appeals to the ecological scientists who are public policy advisors

135 Naess, Ecology, Community and Lifestyle, Op. Cit., p. 24.

136 Ibid., p. 23.

137 Ibid., p. 23. An ethics with regard to non-human nature is also presupposed in Marx's pejorative description of man's historically "necessary" abuse of nature, women and other men. For example: "It is necessary that this appearance be abolished - that landed property, the root of private property, be dragged completely in the movement of private property... that the marriage of convenience should take the place of the marriage of honour with the land; and that the land should likewise sink to the status of a commercial value, like man. It is essential that that which is the root of landed property - filthy self-interest — make its appearance, too, in its cynical form." Marx, Marx Engels Collected Works, Vol 3.,p. 267. 
to include the dynamic human activity of ethical evaluation to their otherwise neutral or "shallow" analyses of change. He does not criticize scientific methods per se, but, like Marx, Naess demands that we rethink what a "fact" is.

Naess defines deep ecology in terms of an ethical "approach" to nature in which scientific facts about nature, like the economic facts of society, are not understood in isolation from the conscious, human active experience of the socio-natural world.

The essence of deep ecology — as compared with the science of ecology, and with what I call the shallow ecological movement — is to ask deeper questions. The adjective "deep" stresses that we ask why and how, where others do not. For instance, ecology as a science does not ask what kind of society would be the best for maintaining a particular ecosystem - that is considered a question for value theory, for politics, for ethics. As long as ecologists keep narrowly to their science, they do not ask such questions. ${ }^{138}$

Marx, like contemporary practitioners of 'shallow ecology,' did not explicitly recognize his ethical system as a premise in his empirical arguments. It has been demonstrated that Naess extends Marx's empirical approach to value into the realm of ethics. Yet, it should be noted that Marx did explore non-economic value. He addresses philosophical questions concerning the ethical value or worth of the commodity system. From his depiction of "oppressed" workers, "greedy" capitalists, and the dialectical path of historical progress toward socio-natural harmony, Marx clearly states his ethical position: commodity production is bad for the workers, is good for the capitalists and is a historically necessary evil which will yield to the good for society as a whole. Marx's ethical assumptions about what is good and what is bad do not enter explicitly into the premises of his entire philosophical argument, although they implicitly influenced his

138 Naess, Arne, "Simple in Means, Rich in Ends," Op. Cit., p. 183. 
entire philosophy. Naess claims that ethical assumptions are at the base of philosophy and that this claim is not based on idealist or religious notions, but rather is based on scientific premises. ${ }^{139}$

Like Marx, Naess is concerned with demonstrating the empirical validity of his method, a method of deep questioning and of announcing one's ethical evaluations of ecological social policies. By his appeal to common sense, Naess claims to have demonstrated that ethical "value priorities" underlie various arguments in support of, or in opposition to, various social policies. However, Naess argues that appeals to common sense do not, and cannot, stand alone as a method for investigating one's ethical assumptions. Rigorous logical analysis is required. He also draws a parallel from mathematical and scientific arguments to show that it is valid for empirically unsupported claims, such as ethical claims, to serve as the foundation for logically consistent arguments. If ethical theory, he reasons, as well as the values from which ethical theory is derived, is presupposed in fact-based arguments which include statements of "valued" change, then values and ethical theory are premises in these arguments. Therefore, uncovering these values, Naess argues, reveals a priori premises, a class of premises which is at the basis of all empirical chains of argument.

\footnotetext{
139 Bookchin, intolerant of any position that does not affirm his historical-dialectical view of the world, vigorously disagrees with Naess's position. "To declare, as Ame Naess, the pontiff of 'deep ecology,' has done, that the 'basic principles of the deep ecology movement lie in religion or philosophy,' is to make a conclusion notable for its absence of reference to social theory." Bookchin, Murray, "Why This Book Was Written," Remaking Society, Op. Cit., p. 12. Bookchin's criticism of Naess (although not of all 'deep ecologists') is, I think, erroneous. Further, unlike Naess, Bookchin regards ethical sensibility, although historically prior to and necessary for the evolution of abstract consciousness, as an unacceptable (non-empirical) premise for analytical argument.
} 
Not everything can be proven - an old thought first emphasised by Aristotle. The string of proofs on any definite occasion must commence somewhere. ... History of mathematics and logic shows a diversity of systems, but they all have rules, some deduced from other rules, but at least one must be simply postulated, without any justification whatsoever. ${ }^{140}$

Naess applies the logic of mathematical systems and logical systems to value theory, arriving at the conclusion that value statements, such as "the flourishing of human and non-human life on Earth has inherent value," can serve as the basis for a logically derived, empirical argument.

2. Value as Based in Concrete Nature - As demonstrated, both Naess and Marx claim that value is an empirical reality, inasmuch as they insist that the inclusion of a social 'value' perspective adds substance to scientific and social-scientific 'factual' knowledge claims. However, unlike Marx's conception of the activity of labor, Naess's understanding of the activities of ethical evaluation and "deep" questioning ${ }^{148}$ are not grounded in human behavior which creates value. Rather, such human activities lead to value judgment concerning the particular human relation to specific, concrete qualities in nature (or rather the entire human and non-human world). This section examines Naess's

${ }_{140}$ Naess, Arne, Ecology, Community and Lifestyle, Op. Cit., p. 68.

${ }_{141}$ The social, political, philosophical implications of human value judgments are an important aspect of the reality which Naess attempts to bring into discussions of 'the facts of the matter' with regard to scientific ecological data. Scientific knowledge, in its use by human society, is political and social. The term "question" in English is an inexact translation of Naess' intent: "But defining the movements [Deep and Shallow ecology] in terms of deepness of questioning is misleading.

The English term questioning is not as forceful as the German and French equivalents: problematizieren, Problematizierung, problematique, etc. In European philosophy and politics during the late " 60 s these terms were important - the whole industrial society was questioned: problematiziert." Naess, "Deepness of Questions and the Deep Ecology Movement," Deep Ecology for the 21st Century, Edited by George Sessions, p. 210. 
understanding of the human process of comprehending value as an external human/nature relation.

Naess turns to a study of the human process of understanding nature to demonstrate empirically that the human/nature relationship gives rise to the human conception of value. Naess claims that assessments of the value of nature are based on concretely real qualities that exist in nature and that are phenomenologically experienced by humans. Marx, by comparison, claims that assessments of the value of nature are based on intrinsic value of the labor that is added to nature and on the instrumental value of the real qualities that exist in nature. Rather than emphasizing particular labor processes which drive historical changes in human/nature relations and in the social value of nature, as Marx does, Naess analyzes the phenomenological process of particular human experiences of nature to demonstrate the concrete basis of value judgments, which are formed from the concreteness of qualities in nature and the relationship which this 'qualitied' nature has with the human perceiver/experiencer.

At the base of Naess's understanding of the concrete qualities of nature is a challenge to the dualist distinction between 'fact' and 'value.' Naess rejects the notion that what is 'good' is subjective and what is 'empirically true' is objective, introducing instead the concept of relationality. Naess argues that "If the term 'objectivity' is meant to imply certainty, intersubjectivity, and stability, scientific texts gain in objectivity when evaluations used as premises are explicitly formulated."142

Some may have received the impression that I have basically concluded that everything is subjective, and that our original distinction

${ }_{142}$ Naess, Ame, Ecology, Community and Lifestyle, Op. Cit., p. 40. 
subjective/objective useless. (sic) This impression should be dispelled if one keeps the following in mind: there is a difference between something relational and something which is no more than an expression of one person's personal judgement. When we say 'the Eiffel Tower is on the left', we describe a state of affairs which does not express individual person judgement. ${ }^{143}$

According to Naess, a discussion of personal values in the context of social policy based on scientifically measurable facts introduces the addition of "knowledge" which is not physically objective the way the number of trees affected by a particular blight may be counted. However, such discussion adds to our knowledge of the facts by contextualizing the discussion as a social state of affairs. By adding an assessment of the particular human/nature relationship under discussion, the context of the "subjective" impression can be understood as an empirically "objective" one.

Naess asserts that particular values (such as the beauty of a landscape or the goodness of a ripe tomato or the preciousness of a human life) and opinions of the intrinsic or instrumental worth of any object emerge from real, concrete qualities in nature through their particular relation to the valuing human subject. For Naess, the relation has an abstract, yet real existence.

Between the items of the world conceived as contents in the forms of gestalts there are internal structural relations, but they do not add to the set of contents. As we are free to conceptualise them in different ways. ... The importance of abstract structural considerations cannot be overestimated, but, like maps, their function is not to add to the territory, the contents, but to make it more visible. The whole Earth is not the Earth plus its maps. ${ }^{144}$

\footnotetext{
${ }^{143}$ Ibid.,pp. 49-50.

144 Ibid., p. 67.
} 
This parallels Marx's demonstration that all economic value is an abstract conception, although based on real quantities of labor and materials in particular relation of their use value in the social marketplace. Both Naess and Marx conceive of value as emerging from the process of the human experience of the world. However, Naess's understanding of value "objectivity" (in the sense of certainty and intersubjectivity) encompasses ethical value, while Marx's investigation of economic value avoids the investigation of ethical value (perhaps as he could not conceive of how to avoid basing ethics on what he considered "speculative" foundations).

Naess argues that without the conscious participation of human beings in the experience of concrete qualities, the very conception of the value of nature is senseless. ${ }^{145}$ He describes the conscious process of the spontaneous experience of nature as one that is the basis for recognition of value in nature. He relies on phenomenological arguments to describe this experience as a non-judgmental openness to nature, an involvement in the world without "deliberately focused"146 perception. "Phenomenological viewpoints are valuable for the development of consciousness of a non-instrumental, non-utilitarian content of the immediate experience of nature."147

Naess's arguments concerning openness to nature reveal a key difference between Marx and Naess. For Naess, particular phenomenological experiences, and not particular activities of labor, establish the value of nature. Naess describes the process of the 'open consciousness' as gestalt thinking in which the concrete and intangible qualities - in

145 Naess, Is It Painful To Think?, p. 9.

146 Naess, Arne, Ecology, Community and Lifestyle, Op. Cit., p. 60.

147 Ibid., p. 51. 
combination - comprise reality. A non-self-conscious or 'open' experience of our surroundings reveals that values are part of the concrete phenomena comprising the individual gestalt experience. The immediate experience when one is absorbed in the world is one of apperception.

When one's attention is not deliberately focused upon perceptual gestalts, all experience is apperceptive. Its units are apperceptive gestalts, not sensory elements, not intellectual elements. The distinction between 'facts' and 'values 'only' emerges from gestalts through the activity of abstract thinking. The distinction is useful, but not when the intention is to describe the immediate world in which we live, the world of gestalts, the living reality, the only reality known to us. ${ }^{148}$

So for Naess, values arise from concrete qualities that are apperceived in the open experience of the world. As value necessarily involves both the valuer and the valued, values are neither objective nor subjective, but emerge in the human relation to the world from the qualities of the phenomenal world.

Further, in order to argue that characteristics, yielding values within the context of human relations, are embedded in the concrete contents of the world, Naess rejects the modem philosophic concept of the thing in itself, which is based in the "strong philosophical tradition [that] goes from Newton to Kant." 149 Instead he argues that by reducing the 'objectivity' of things to a set of abstract qualities common for all observers, the 'thing' gets stripped of its specific size, shape, color, taste, beauty and the complex of qualities which generates impressions such as the beautiful, dreary or pathetic. 150 Naess

\footnotetext{
148 Ibid., p. 60.

149 Ibid., p. 48.

150 Naess argues that modern philosophy relegates all but the primary qualities of nature as "objective," whereas Naess includes the qualities of felt experience in the description of concrete reality. See Ecology, Community and Lifestyle, pp. $51-54$.
} 
claims that the resultant abstract description bears no resemblance to the 'thing' in question. The unique and particular set of qualities that defines a thing in the natural world is denied.

A good deal is common for all dogs, but the attempt to imagine a dog which has the common, and onty the common features of all dogs overlooks not only colour but everything which distinguishes a bulldog from a terrier. A nature consisting solely of the features about which we are continuously in agreement is like such a spectral dog - therefore any objective notion of nature cannot be seen as that which we all agree upon as being 'there. ${ }^{151}$

Naess asserts that when we are involved in the observation of other objects, 'we' seem to disappear and the 'other' (a worm, a river, whatever) is valuable in that it possesses specific, concretely 'there' qualities, such as a striving for life, an order, beauty, strength, grace, etc. ${ }^{152}$ Through these concretely 'there' qualities, the value of concrete nature is real. It is based on given concrete complexes of independently existing qualities which are experienced. Thus, it can be concluded that Naess's rejection of the abstract modem approach is one that is grounded in the ordinary human experience of the physical contents of the world — what "we all agree upon as being 'there." Recall that Marx added human experience (in the form of specific and concretely real labor) to his understanding of the reality of the thing-itself, thus also rejecting the in-itself and for-itself distinction. The quality of labor, which when embodied in a thing gives it

\footnotetext{
151 Ibid., p. 49.

152 Bookchin's definition of sensibility (the basis for moral value and organic process thinking in social ecology) also requires that the actual experiencing of moral values involves a certain 'openness' to the world in which we are situated: "such an ethic retains its openness to the richness of human sensibility as the embodiment of sensibility itself at all levels of organic and social evolution." Bookchin, Ecology of Freedom, Op. Cit., p.
} 353. 
value, is really 'there' in the thing and serves as the basis for abstraction. For Naess, these qualities which we perceive as valuable exist in nature and are discovered through the human experience of nature, while for Marx, the qualities which we perceive as valuable exist in nature by virtue of human activity. Despite these differences, it can be concluded that both Naess and Marx reject the modern view of the thing-itself.

Recall that Marx, like Naess, posits intrinsic value as a characteristic of the concrete world, although indirectly through labor. Marx also combines instrumental and intrinsic value, conceiving of instrumental value as the intrinsic value of labor embedded in a natural/material, useful object. In the 1844 Manuscripts, Marx asserts that the instrumental value of nature exists to the extent that nature has been self-consciously acted upon as a means to a human end, while its intrinsic value implicitly exists: Human beings are intrinsically valuable, and they are part of nature. By extension, we can say that nature is also intrinsically valuable insofar as it is self-consciously acted upon by human beings. Thus Marx values the humanity that he discerns in non-human nature, yet maintains the distinction between instrumental value and intrinsic value. In contrast, Naess collapse the distinction, conceiving of the intrinsic/instrumental value distinction as part of a dualist division separating value from the valued and the valuer, hence denying the basic relationality of value. Naess defends his claim of the concreteness of value by demonstrating how the concrete experience of nature gives rise to the pre-theoretic perception of value. 
Conclusion: In conclusion, it can be stated that Naess, using the contemporary language of "systems and relational perspcctives,"" 53 and Marx, using the language of dialectics, both conceive of value theory in terms of an interactive relation between the individual, life-experiencing human and the socio-natural world. In examining Naess' conception of the value of nature, it can be stated that Marx's "naturalist" method and critique of strict empiricism is echoed by Naess. Both philosophers provide a detailed analysis, based on concrete examples drawn from human experience, to demonstrate the relationship between concrete reality and the abstract reality of perceptions of value. Although they differ in which abstract values are added, for Marx it is labor and for Naess it is ethics, they are kindred in approaching philosophy as a living or modified empiricism.

153 Naess, Ame, Ecology, Community and Lifestyle, Op. Cit., p. 36. 
CONCLUSION

The naturalist-humanist foundation of Marx's philosophy is the result of his effort to base philosophy on the human experience of human/nature unity, a unity which incorporates consciousness, social relations and value theory into an understanding of the natural world. Marx's realism and his turn to human/nature relations as the founding premises of philosophy form an approach to philosophy that is recapitulated by Bookchin, Warren and Naess - each of whom furthers Marx's work. Each continues the process of removing "idealist" premises from philosophy and probes the human/nature relation to understand the meaning of human consciousness in its analytical and ethica] aspects.

It has been demonstrated that Marx's philosophical framework and approach to the issue of human-nature relations has proved to be a source of ideas and direction for those philosophers faced with the task of expressing a new kind of human-nature relationship.

Marx's shift away from traditional idealism and materialism has served as a guide to Bookchin, as shown by Bookchin's direct adaptation of Marx's dialectical-historical approach both to the progress of human/nature relations and to structuring the problem of the origins of human consciousness in nature. In Warren's case, it has been demonstrated that the theoretical foundations of ecofeminism rely heavily on Marxist and socialist traditions and that the feminist pluralist components of ecofeminism can be understood as an extension of Marx's emphasis on the particular context of human socio-historical reality. Arne Naess, whose methods of philosophy bear the least resemblance to those of Marx, is nevertheless pre-occupied with a problem that was of central concern to Marx: 
the inclusion of the human assessment of the value of nature into the analysis of human/nature relations and social reality.

While the metaphysical shift from idealism to dialectical materialism led by Marx serves as a guide to Bookchin, Warren and Naess, Marx's own view of nature and nature relations has been modified or in some instance superseded by these ecological philosophers for a variety of reasons discussed throughout this thesis. Despite differences of approach to both ecological philosophy and the Marxist heritage, Bookchin, Waren and Naess agree on the reality of the interrelatedness of the human and non-human aspects of nature and on the social necessity of recognizing nature as more than of instrumental value to humanity. All four thinkers unanimously regard as a problem the lack of recognition given to human needs and values as part of economic decision-making; such neglect leads in their view to disastrous social policy — with disastrous ecological consequences as well.

While Marx's philosophy serves as a model for Bookchin, Warren and Naess, his work does not reflect a genuine and non-theoretical concern for non-human nature. It is the task of contemporary social/ecological philosophers to incorporate Marx's critique of socio-economic problems within the larger framework of a social-natural environment.

It is hoped that clarifying the relationship between human and non-human nature as understood by Karl Marx, and comparing his views to three different thinkers with respect to the concept of human consciousness in relation to intrinsic value, will prompt further comparisons on topics such as the impact of human/nature relations on the concept of human identity, social action and the politics of environmentalism. 
APPENDIX

German philosopher Karl Marx (1818-1883) is commonly regarded as the father of modern communism or scientific socialism. The posthumous discovery of the 1884 Economic and Philosophic Manuscripts and the German Ideology, and their publication in 1927 and 1932, respectively, provided the opportunity for a renewed look at Marx's thought. These works can be understood as supporting the interpretation of Marx as opposed to all forms of idealism -- even communist idealism -- as the foundation for political action and philosophic theory.

American philosopher Murray Bookchin has written extensively over the last forty years on anarchistic, utopian and environmental philosophy. Dominant themes include freedom, naturalism and material dialectics. Bookchin cofounded the Institute for Social Ecology (ISE), based in Plainfield, Vermont. He is the Director Emeritus of ISE and Professor Emeritus at Ramapo College in New Jersey.

Karen J. Warren is an Associate Professor of Philosophy at Macalester College, St. Paul, Minnesota. Her teaching and research focus on ecofeminism and environmental ethics. She has published articles in various philosophy joumals since 1987 . Recently she has co-edited two books, Ecofeminism: Women, Culture, Nature and Bringing Peace Home. She is the editor of "Ecological Feminist Philosophies."

Norwegian philosopher and world-class mountain climber Ame Naess established a reputation as a thinker among members of the Vienna circle in the mid-1930's. Earning a doctorate with a thesis on positivism, Naess taught in and for many years chaired the philosophy department at the University of Oslo, Norway from 1936 through 1970 . His work on the pluralism of meanings earned him a commission by UNESCO in 1949 to define 'democracy.' He is active in the 'deep ecology' movement, and his remains active at the university through the Centre for Development and the Environment. 


\section{BIBLIOGRAPHY}

Abbagnano, Nicola, trans. by Languilli, Nino, "Humanism," p. 69-70, Encyclopedia of Philosophy, Vol. 4, (New York: Macmillan Publishing Co., Inc. \& The Free Press), 1972.

Buege, Douglas J., "Rethinking Again," in Ecological Feminism, Editor, Warren, Karen J., 42-63.

Blau, Joseph L., "Toward a Definition of Humanism," The Humanist Alternative, Kurtz, Paul, Editor (London: Pemberton Publishing Co., Ltd.), 1973.

Bookchin, Murray, The Ecology of Freedom: The Emergence and Dissolution of Hierarchy (Pal Alto, CA: Cheshire Books), 1982.

, The Modern Crisis (Philadelphia: New Society Publishers), 1986.

,The Philosophy of Social Ecologv: Essays on Dialectical Naturalism (Montreal:

Black Rose Books), 1990.

, Post-Scarcity Anarchism (Berkeley, CA: The Ramparts Press), 1971.

, "Recovery Evolution: A Reply to Eckersley and Fox, Environmental Ethics, Vol. 11, No. 1, Spring 1989, pp. 253

Press), 1990.

Remaking Society: Pathways to a Green Future (Boston, MA: South End , Toward an Ecological Society (Montreal: Black Rose Books), 1980.

Capra, Fritjof, The Turning Point: Science, Society and the Rising Culture, (New York: Simon \& Schuster), 1982.

Cheney, Jim, "Eco-Feminism and Deep Ecology," Environmental Ethics, Vol. 9, 1987.

, Book Review: "Ame Naess: Ecology, Community and Lifestyle: Outline of an Ecosophy," Environmental Ethics, Vol. 13, No. 3, Fall 1991.

Clark, John, "Introduction, Part Four: Social Ecology, Environmental Philosophy: From Animal Rights to Radical Ecology, General Editor Michael E. Zimmerman.

Devall, Bill. Deep Ecology, (Salt Lake City: Peregrine Smith Books), 1985. 
Descombes, Vincent, Modern French Philosophy, Trans. by L. Scott-Fox and J. M. Harding (Cambridge: Cambridge University Press), 1993.

Eckersley, Robyn, "Divining Evolution: The Ecological Ethics of Murray Bookchin," Environmental Ethics, Vol 11, No. 2, Summer 1989, pp. 99-116.

Edwards, Paul, Editor-in-Chief, Encyclopedia of Philosophy, Vols. 1-8, (New York: Macmillan Publishing Co., Inc. \& The Free Press), 1972.

Fox, Warwick, "Deep Ecology: A New Philosophy of our Time," The Ecologist, v. 14, 5-6, 1984, pp. 194-200.

, "The Deep Ecology-Ecofeminism Debate and Its Parallels," Environmental Philosophy: From Animal Rights to Radical Ecology, Gen. Ed. Michael E. Zimmerman, pp.213-232.

, Towards a Transpersonal Ecology: developing new foundations for environmentalism (Boston: Shambhala; New York: distributed in U.S. by Random House), 1990.

Glasser, Harold, "On Warwick Fox's Assessment of Deep Ecology," Environmental Ethics, Vol. 19, Spring I997, pp. 69-85.

Gould, Carol C., Marx's Social Ontology: Individuality and Community in Marx's Theory of Social Reality (Cambridge, MA: The MIT Press), 1978.

Grundmann, Reiner, Marxism and Ecology (Oxford: Clarendon Press), 199I.

Hancock, Roger, "The History of Metaphysics," p. 289-290, Encyclopedia of Philosophy, Vol. 5, (New York: Macmillan Publishing Co., Inc. \& The Free Press), 1972.

Hirst, R. J., "Realism," p. 77, Encyclopedia of Philosophy, Vol. 7, (New York: Macmillan Publishing Co., Inc. \& The Free Press), 1972.

Hook, Sidney, From Hegel to Marx (Michigan: The University of Michigan Press), 1962.

Kraut, Richard, Editor, The Cambridge Companion to Plato (Cambridge: Cambridge University Press), 1992.

Kurtz, Paul, Editor, The Humanist Alternative (London: Pemberton Publishing Co., Ltd.), 1973.

Lawler, James, “The Marxian Dialectic," pp. 48 - 53, Monthly Review, Vol. 46, No. 9, February 1995. A book review of Bertell Ollman's Dialectical Investigations. 
Leopold, Aldo, A Sand County Almanac, (New York: Oxford University Press, Inc.) 1987.

List, Peter, C., Ed., Radical Environmentalism: Philosophy and Tactics, (Belmont, CA: Wadsworth, Inc.), 1993.

MacGregor, The Communist Ideal in Hegel and Marx, (Toronto, Canada: University of Toronto Press, Inc.), 1984.

Martin, John N., "Order Theoretic Properties of Holistic Ethical Theories, Environmental Philosophy, Vol. 13, No. 3, Fall 1991, pp. 215-234.

Marx, Karl, Capital, Vol. I, Trans. by Fowkes, Ben (New York: Vintage Books), 1977. , Collected Works 3, (New York: International Publishers), 1975. , Grundrisse, Trans. Martin Nicolaus (New York: Vintage Books), 1973. , The Marx-Engels Reader, Ed. by Tucker, Robert C. (New York: W. W. Norton \& Company, lnc.), 1972.

McClellan, David, The Young Hegelians and Karl Marx, (London, Macmillan and Co. Ltd.), 1969.

McDaniels, Jay, "Physical Matter as Creative and Sentient," Environmental Ethics, Vol. 5, No. 4, Winter 1983, pp. $291-317$.

Miller, Peter, "Descartes' Legacy and Deep Ecology," Dialogue, XXVIII (1989), pp. 183-202.

Naess, Ame, "A Defence of the Deep Ecology Movement," Environmental Ethics, Vol. $6,1984$.

Ecology, Community and Lifestyle. Outline of an Ecosophy, Tr. by Rothenberg, David, (Cambridge: Cambridge University Press), 1989.

"Identification as a Source of Deep Ecological Attitudes," Deep Ecology, Michael Tobias, Ed, (San Diego: Avant Books), 1985, pp. 256-270. pp. 201-204. "Intuition, Intrinsic Value and Deep Ecology," The Ecologist, v. 14, 5-6, 1984, 
, "Man Apart and Deep Ecology: A Reply to Reed," Environmental Ethics, v. 12, 1990, pp. 185-192.

" "Simple in Means, Rich in Ends," pp. 182-192 in Envirommental Philosophy: From Animal Rights to Radical Ecology, Gen. Ed. Zimmerman, Michael E. Originally published in The Ten Direction, Los Angeles Zen Center, 1982.

, "The Deep Ecological Movement: Some Philosophical Aspects," pp. 193-212 reprinted in Environmental Philosophy: From Animal Rights 10 Radical Ecology. Essay originally appeared in Philosophical Inquiry, Vol III., No, 1-2, 1983, pp. 10-31.

,The Pluralist and Possibilist Aspect of the Scientific Enterprise (London: Allen \& Unwin and Oslo: Universitetsforlaget), 1972.

"The Shallow and the Deep, Long-Range Ecology Movement: A Summary," reprinted in List, Peter C., Radical Environmentalism: Philosophy and Tactics (Belmont, CA: Wadsworth, Inc.), 1993, pp. 19-24. Originally printed in Inquiry, 16, Spring 1973, pp. $95-100$.

Parsons, Howard, L., Humanism and Marx's Thought (Springfield, IL: Charles C. Thomas Publisher), 1971.

Plumwood, Val, "The Ecopolitics Debate and the Politics of Nature," in Ecological Feminism, Editor, Warren, Karen J., 64-87.

Poster, Mark, Foucault, Marxism \& History, (Cambridge: Polity Press), 1984.

Ramsperger, A. G., Critical Realism," p. 261, Encyclopedia of Philosophy, Vol. 2, (New York: Macmillan Publishing Co., Inc. \& The Free Press), 1972.

Reed, Peter, "Man Apart: An Alternative to the Self-Realization Approach", Environmental Philosophy, Vol 11, No. 1, Spring 1989, pp. 53-69.

Reed, Peter and Rothenberg, David, Editors, Wisdom in the Open Air, (Minneapolis: University of Minnesota Press), 1993.

Ricouer, Paul, Lectures on Ideology and Utopia, Edited by George H. Taylor (New York: Columbia University Press), 1986.

Rothenberg, David, Is It Painful to Think?: Conversations with Arne Naess (MN: University of Minnesota Press), 1993.

Scheler, Max, Man's Place In Nature, translated by Meyerhoff, Hans (New York: The Noonday Press), Fifth Printing, 1971. 
Sessions, George, Deep Ecology for the 21 ${ }^{\text {st }}$ Century, (Boston: MA: Shambhala Publications, Inc.), 1995.

Sewart, John, "Verstehen and dialectic: epistemology and methodology in weber and lukacs," Philosophy and Social Criticism, 1978, n. 3-4, pp. 321-366.

Simon, Thomas W., "Varieties of Ecological Dialectics," Environmental Ethics, Vol. 12, No. 3, Fall 1990, pp. $211-231$.

Slicer, Deborah, "Wrongs of Passage," in Ecological Feminisn, Edited by Karen J. Warren, pp. 29-41.

Ulam, Adam B., Expansion and Coexisience: Soviet Foreign Policy 1917-73, (New York: Praeger Publishers), 1974.

Von Boeselager, Wolfhart F.,"The Soviet Critique of Neopositivism, Blakeley, T. J., Trans., Sovietica, Vol. 35, Prof. Dr. Bochenski, J.M., Ed. (Boston-U.S.A.: D. Reidel Publishing Company), 1974.

Wahl, Jean Andre, A Short History of Existentialism, Translated by Forrest Williams and Stanley Maron (Westport, Conn., Greenwood Press), 1971.

Warren, Karen J., "Critical Thinking and Feminism," Informal Logic, Vol. 10, no. 1 (Winter 1988): 31-44.

, Editor, Ecological Feminism, (New York: Routledge), 1994.

,"Feminism and Ecology: Making Connections," Environmental Ethics, Vol. 9, No. 1, 1981, pp. 3-20.

"Introduction to Ecofeminism," List, Peter C., Radical Environmentalism: Philosophy and Tactics (Belmont, CA: Wadsworth, Inc.), 1993, pp. 81-90.

"Introduction - Part Three: Ecofeminism" pp. 253-267 in Environmental Philosophy: From Animal Rights to Radical Ecology.

"The Power and the Promise of Ecological Feminism," Environmental Ethics Vol. 12., No. 3, Summer 1990, pp. 125-146.

,"Toward an Ecofeminist Ethic," Studies in the Humanities, Vol. 15 (1988).

Warren, Karen J. and Cheney, Jjm, "Ecosystem Ecology and Metaphysical Ecology: A Case Study," Environmental Ethics, Vol. 15, No. 2, Summer 1993, pp. 99-106. 
Zimmerman, Michael E. "Feminism, Deep Ecology and Environmental Ethics," Environmental Ethics Vol. 9, No. 1, Spring 1987, pp. 21-44.

Gen. Ed. Environmental Philosophy: From Animal Rights to Radical Ecolog?' (Englewood Cliffs, NJ: Prentice Hall, Inc.), 1993. 